\title{
Textiles from the Museum of San Isidoro (León): New Evidence for Re-evaluating Their Chronology and Provenance
}

\author{
Ana Cabrera Lafuente \\ Museo del Traje, Madrid \\ Honorary Senior Research Fellow, Victoria and Albert Museum \\ ana.cabrera@cultura.gob.es
}

\begin{abstract}
This paper presents the first in-depth analysis of the textiles held by the Museo de la Real Colegiata de San Isidoro de León, providing a careful investigation of textile features and raw materials, in addition to carbon-14 dating and archival research. These new data have allowed us to redate the fabrics, placing them within their tenththrough early thirteenth-century Mediterranean and European contexts. The result is a more complex image than was previously assumed, and it offers a significant starting point for further research into the roles played by textiles in medieval Iberia.
\end{abstract}

\section{Keywords}

al-Andalus - Byzantium - carbon-14 dating - Central Asia - embroidery - Kufic inscriptions - metal threads - silk

\section{Introduction}

Textiles as a form of evidence continue to be insufficiently incorporated into larger studies of medieval history, though they have been gaining visibility in recent years. Yet the textiles from the museum of the Real Colegiata de San Isidoro de León have been known in Iberian art history since the study by Manuel Gómez-Moreno in the early 1900s. ${ }^{1}$ His discussion of the textiles from

1 Gómez-Moreno prepared the documentation in 1905 and 1906, though the publication did not appear for another two decades. Manuel Gómez-Moreno, Catálogo monumental 
San Isidoro, as part of the Catálogo Monumental de León, while brief, is the only one that presents the complete set, most of them classified as "telas árabes" (Arabic or Islamic fabrics). Following Gomez-Moreno, the textiles are mentioned partially by Kendrick, ${ }^{2}$ in May's book about medieval silks from Spain, ${ }^{3}$ and in Partearroyo's articles on silk textiles of al-Andalus. ${ }^{4}$ In addition, these textiles have appeared in several exhibition catalogues, from the International Exhibition of Barcelona in 1929 (Fig. 1$)^{5}$ to the Maravillas de la España Medieval in 2000, yet they have not been the subject of in-depth research until now. ${ }^{6}$

In 2017, a research project combining an interdisciplinary team under the direction of Therese Martin ${ }^{7}$ carried out on-site research on the treasury of San Isidoro and its context. ${ }^{8}$ During three days in March 2017, we had full access to the collection, allowing us to document the textiles with macro photographs of the weaves and taking samples for radiocarbon analyses and for characterization of the fibers, dyes, and metal threads. ${ }^{9}$ The textiles were documented through digital photography, recording their dimensions, size of the patterns, technical details such as selvedges, thread twist, and loom mistakes (Figs. 2a-b). This documentation of the techniques together with careful study of how the textiles were applied to the caskets took most of our time

de España. Provincia de León (Madrid: Ministerio de Instrucción Pública y Bellas Artes, 1925-1926). The original is available online at http://biblioteca.cchs.csic.es/digitalizacion tnt/index_interior_leon.html.

2 Alfred Kendrick and Ruvon Guest, "A Silk Fabric Woven in Baghdad," The Burlington Magazine for Connoisseurs 49-285 (1926): 261-267.

3 Florence Lewis May, Silk Textiles of Spain. Eighth to Fifteenth Century (New York: Hispanic Society of America, 1957), 24-27, figs. 14-16.

4 Cristina Partearroyo, "Los tejidos en Al-Andalus entre los siglos IX al XV" and "Las colecciones de seda y los archivos," in España y Portugal en las rutas de la seda. Diez siglos de producción y comercio entre Oriente y Occidente (Barcelona: Universitat Autònoma, 1996), 58-73 and 317-328.

5 Manuel Gómez-Moreno, El Arte en España. Guía del Museo del Palacio Nacional. Exposición Internacional de Barcelona (Barcelona: Imprenta de Eugenio Subirana, 1929), salas 7 y 13.

6 Isidro Bango, ed., Maravillas de la España Medieval (Valladolid: Junta de Castilla y León, 2001).

7 The Medieval Treasury across Frontiers and Generations: The Kingdom of León-Castilla in the Context of Muslim-Christian Interchange, c. 1050-1200, National Excellence in Research Grant, Spanish Ministry of Economy and Competitivity, HAR2015-68614-P. I would like to thank Therese Martin for her support and assistance during the article preparation and English edition of the text.

8 Special thanks to Raquel Jaén and the museum staff for their support.

9 For the purposes of this article, I have had access to the preliminary results of the analyses, which will be published fully by Laura Rodríguez Peinado. A general view of the analyses carried out by this project will be published in Enrique Parra, "Caracterización de materiales de textiles medievales españoles II" in Laura Rodríguez Peinado y Francisco de Asís García García (eds.), Arte y producción textil en el Mediterráneo medieval (Madrid: Ediciones Polifemo, forthcoming). 


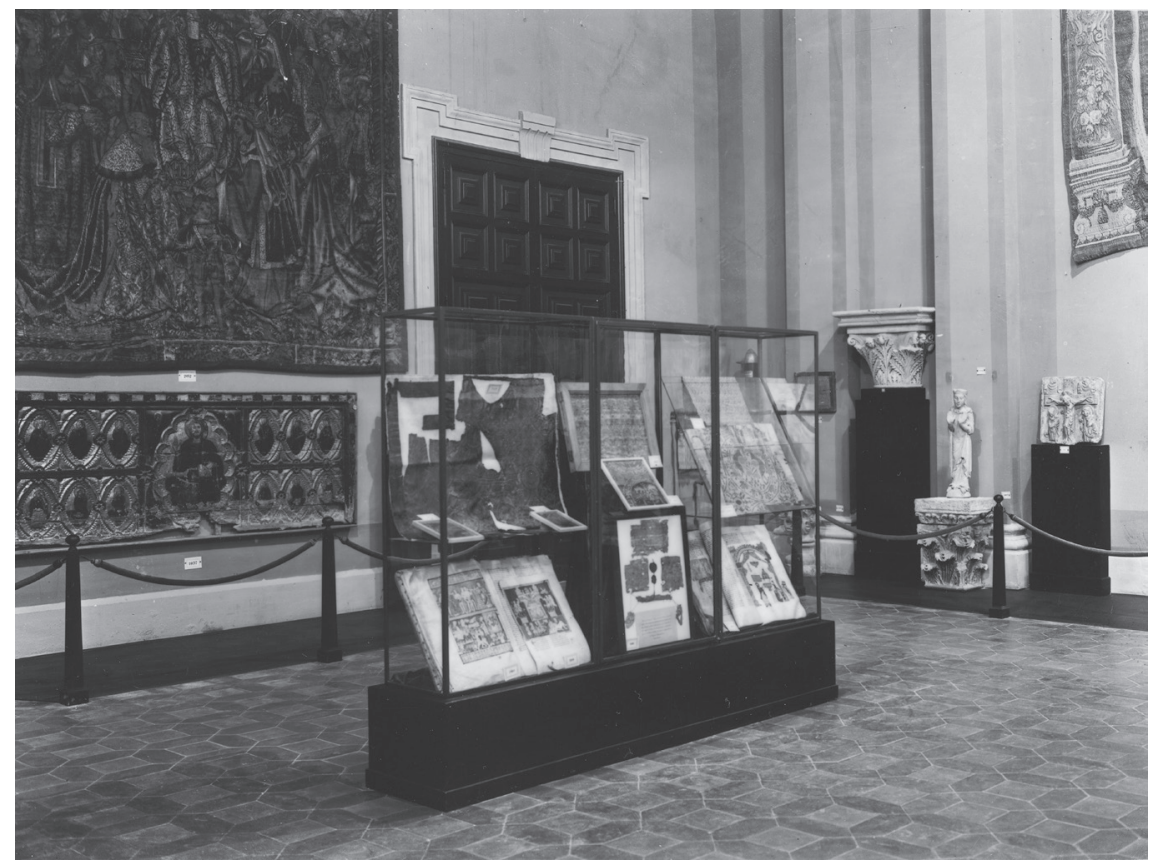

FIGURE 1 Room number 13, Arte de España, at the International Exhibition of Barcelona in 1929. The showcase displayed some of the textiles and artworks from San Isidoro. PHOTO: ARXIU FOTOGRÀFIC DE BARCELONA, AFM12461

during this intensive campaign. Due to the restoration carried out around 2000 in preparation for the Maravillas exhibition, most of the textile fragments are now lined, with a small window left open at the back to reveal the reverse of the fabric (Figs. 3a-b); however, these openings are not sufficient to study fully all details of the techniques on the reverse of each textile.

Written sources concerning these textiles from the medieval and early modern period are very scant. Among them, the one naturally highlighted by scholars is the donation made by King Fernando and Queen Sancha in the "1063 charter" that includes: golden stoles with luxury silver fabric (amoxerce) worked with gold, a luxury silver fabric (adamorcece) with enamel or glass appliqué worked with crystal or enamel (olouitrea), ${ }^{10}$ three altar frontals embroidered with gold (aurifriso), a large brocaded veil (lotzori) and two small ones with ermine fur; two gold embroidered (aurifriso) mantles, one gold embroidered textile (algexi), and one purple textile from a Byzantine

10 Olovitrea is related to the enamel work, here perhaps referring to the enamel or glass beads applied to the fabric, in a similar way to Opus Anglicanum embroidery. 

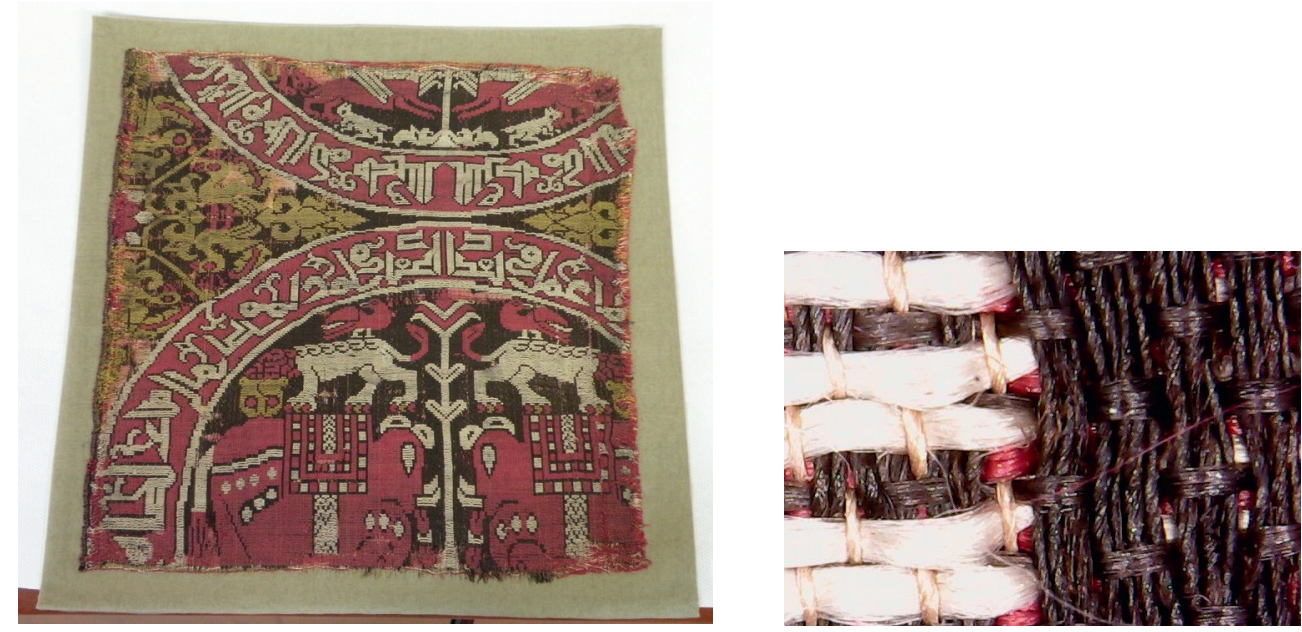

FIGURES 2A AND 2B The so-called Baghdad silk (Table 1, no. 8), with the left selvedge (2a). The white and black warps have a $\mathrm{Z}$ twist, and the white and red wefts are almost un-twisted $(2 b)$.

PHOTOS: AUTHOR

workshop (grizisco, Greek); a chasuble embroidered in gold and two dalmatics made with the same technique. ${ }^{11}$ Regarding these written sources, most of the textiles from San Isidoro, especially those in the caskets, are assumed in the historiography to be the same ones described in the "1063 charter," despite the fact that none of the surviving pieces can easily be matched to the abovelist.

Concerning the different tests and analyses now available to characterize the materials of historical artworks overall and textiles specifically, the last

11 The references to textiles in the "1063 charter" are: "stolas aureas cum amoxerce argenteo et opera ex auro, et aliud argenteum adamorcece habet opera olouitrea ... frontales tres aurifrisos, uelum templo lotzori maiore cum alios duos minores arminios; mantos duos aurifrisos alio alguexi auro texto cum alio grizisco in dimisso cardeno; Casula aurifrisa cum dalmaticis duabus aurofrisis et alia aluexi auro texta." According to Pérez Rodríguez algexi is "a silk cloth embroidered with gold" and lotzori "a brocaded fabric." See Estrella Pérez Rodríguez, "El léxico de los textos asturleoneses (s. VIII-1230): Valoración," in Estudios de latín medieval hispánico: Actas del V Congreso Hispánico de Latín Medieval, ed. José Martínez Gázquez, Óscar de la Cruz Palma, Cándida Ferrero Hernández (Florence: SISM EL, 2012), 950. For the "1063 charter," see María Encarnación Martín López, "Un documento de Fernando I de 1063: ¿Falso diplomático?” in Monarquía y sociedad en el reino de León. De Alfonso III a Alfonso VII, II, Fuentes y Estudios de Historia Leonesa 118 (León: Centro de Estudios e Investigación San Isidoro, 2007), 513-540. See also the discussion by Therese Martin in the introduction to this volume, "Caskets of Silver and Ivory from Diverse Parts of the World: Strategic Collecting for an Iberian Treasury." 

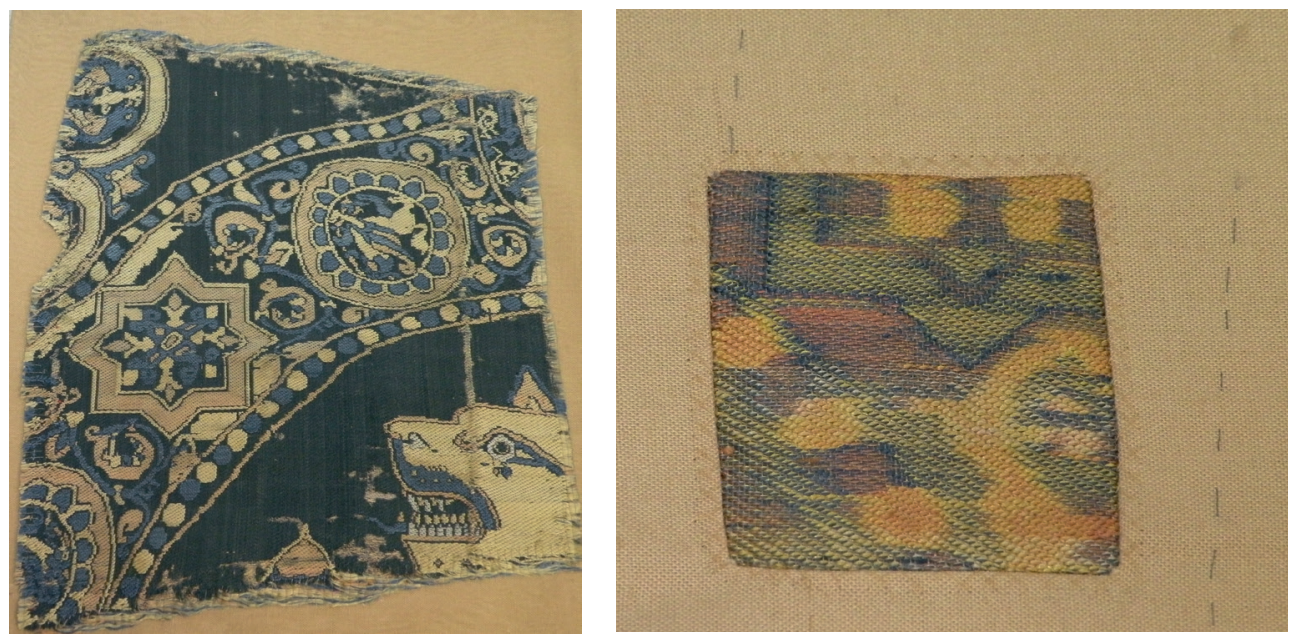

FIGURES 3A AND 3B Textile no. 11 showing faded front view and window the back with multicolored wefts of the same textile PHOTOS: AUTHOR

twenty years have seen great advances. These new types of studies have been very useful in recent investigation especially of Late Antique textiles from Egypt, among other materials. ${ }^{12}$ Such studies have a close link to those using archaeometric techniques, whose objectives can be summarized as the application of scientific analysis to archaeological material. ${ }^{13}$ Such techniques help us to contextualize these artworks, as most of the objects are held in museums or church treasuries, with no clear or known original context.

This methodology allows us to comprehend the material reality of each textile, using carbon-14 analysis to provide data about the moment the raw materials were collected. It also informs us about the fibers, dyes, metal threads, weaves, and looms used in their manufacture, along with a possible primary function of the cloths. Historical textiles are a fragile remnant of the past; this evidence needs to be assessed carefully as a partial source towards a complex, rich, and varied reality, as reflected by the written record. To reach a complete understanding of medieval textiles in context, a combination of efforts among specialists and scholars from different fields of study is needed.

12 Laura Rodríguez Peinado and Ana Cabrera Lafuente, La investigación textily nuevos métodos de estudio (Madrid: Museo Lázaro Galdiano, 2014: http://www.flg.es/images/publicaciones/investigacion-textil-nuevos-metodos.pdf). See also Journal of Medieval Iberian Studies 8.2 (2016) for a special issue focused on cultural patrimony.

13 These include dating methods, artefact studies, mathematical methods, remote sensing techniques, conservation science, and the study of humans and their environment. 
Due to the large amount of data pertaining to each textile held by the museum of San Isidoro, I have provided a compressed summary of their characteristics in Table 1 which appears at the end of the text. ${ }^{14}$ These features are used to present our ideas ${ }^{15}$ about the biography of some of the textiles, from their commencement as raw materials through their installation at San Isidoro. ${ }^{16}$

\section{1 \\ The Textile Materiality: Raw Materials, Color, and Weaves}

The textiles at San Isidoro include eleven fragments (numbered 1 to 11 in the Table), a stole and maniple set, and a lined box (numbers 12 to 14 ). ${ }^{17}$ In the following pages, I will present these fabrics, highlighting the similarities and differences both within the Isidoran group and among textiles from the same period across a broad geographical range from Byzantium, the Near East, Europe, and al-Andalus. I offer a fresh understanding of the textiles based on technological, iconographical, and chronological approaches, adding heretofore unknown information about materials, textile techniques, and provenance to create a more complete picture of these works in context.

Silk is the common thread connecting all the textiles at San Isidoro. This raw material is a very well-known Chinese fiber, with qualities such as a continuous filament, resistance, and ease of dyeing that facilitated the development of textiles with rich decorations. These fabrics spread from China to Central Asia and the Mediterranean in Antiquity; the cultivation of silk arrived in Iberia some time after the third quarter of the eighth century, ${ }^{18}$ according to the

14 The data summarized here represent preliminary conclusions for which a second phase of study is still needed to confirm or modify these ideas. Funding for the analyses of carbon-14 and raw materials was generously provided by the research project Las manufacturas textiles andalusíes: caracterización y estudio interdisciplinar (HAR2014-54918-P), led by Laura Rodríguez Peinado.

15 This article indebted to with the comments from the speakers and attendees at The Medieval Iberian Treasury in the Context of Muslim-Christian Interchange Symposium organized by the Princeton Institute for International and Regional Studies at Princeton University and led by Pamela Patton and Therese Martin.

16 For the importance of the study of an object's materiality, see Michael Yonan, "Toward a Fusion of Art History and Material Culture Studies," West 86. A Journal of Decorative Arts, Design History, and Material Culture, 18.2 (2011): 232-248, esp. 233-234.

17 The late medieval embroidery known as the Pendón de San Isidoro was not included in this campaign. We hope to study it in a second phase.

18 For a recent overview of silk in al-Andalus, see David Jacoby, "The Production and Diffusion of Andalusi Silk and Silk Textiles, Mid-Eighth to Mid-Thirteenth Century," in The Chasuble of Thomas Becket: A Biography, ed. Avinoam Shalem (Chicago: University of Chicago Press, 2017), 142-153. 
Liber Pontificalis that mentions silk textiles from Hispania in the first half of the ninth century. ${ }^{19}$ This fiber was highly appreciated and was part of tax payments, diplomatic gifts, and khila' or robes of honor. ${ }^{20}$ A product of state monopolies or royal workshops in Iberia and the Byzantine Empire, ${ }^{21}$ silk could not be cultivated beyond the 4oth parallel north. ${ }^{22}$

A second fiber used on just one of the textiles at San Isidoro is linen, known in Europe and North Africa from prehistory and cultivated in the south of the Iberian Peninsula. Egypt and Iberia were the most renowned places of linen production during the Middle Ages. ${ }^{23}$

Both fibers require different processes to obtain the material for spinning and dyeing. These processes were carried out by specialized workers, as Shatzmiller has shown in her publication on labor in medieval Islam; the Arabic textile vocabulary is very rich and speaks of its specialization. ${ }^{24}$

A third type of fiber that is found in five of the textiles in the collection at San Isidoro are metal threads. These have enriched textiles since Antiquity, but it was during the medieval period that metal threads witnessed a great development, related to improvements in metallurgy. ${ }^{25}$ During our initial investigation of the embroidery (Table 1, no. 2), we seemed to detect two types of metal threads: a flat metal sheet glued to an organic material (such as parchment) and wrapped around a silk thread, in the embroidery ${ }^{26}$ and a flat metal

19 In the Liber Pontificalis, silks are described as "vela spanisca," "vela de spanisco," or "vestes de spaniscu," Louis Duchesne, Le Liber Pontificalis. Texte, introduction et commentaire par L. Duchesne (Paris: 1892), 2:75, 107, 122, 132; cit. May, Silk Textiles, 3, note 5.

20 Lisa Golombeck, "The Draped Universe of Islam," in Content and Context of Visual Arts in Islam, ed. Priscilla Soucek (State College, PA: Pennsylvania State University Press, 1988), 25-34; Louise Mackie, Symbols of Power: Luxury Textiles from Islamic Lands, 7 th-21st Century (Cleveland: Cleveland Museum of Art, 2016), 7-30, at 28-29.

21 Anna Muthesius, "Essential Processes, Looms, and Technical Aspects of the Production of Silk Textiles," in The Economic History of Byzantium: From the Seventh through the Fifteenth Century, ed. Angeliki E. Laiou (Washington: Dumbarton Oaks, 2002), 147-168.

Maurice Lombard, Les textiles dans le monde musulman, VII ${ }^{e}-X I I^{e}$ siècle (Paris-La HayeNew York: Mouton, 1978). The south of France is the northeasternmost area of Europe where silk cultivation is possible.

23 Lombard, Les textiles dans le monde musulman, $5^{1-53}$.

24 Maya Shatzmiller, Labour in the Medieval Islamic World (Leiden: Brill, 1994), 119-123 and 240-250.

25 Márta Járó, "Gold Embroidery and Fabrics in Europe: XI-XIV Centuries," Gold Bulletin 23.2 (1990): 40-57; Anna Karatzani, "Metal Threads: The Historical Development," (http:// conferences.saxo.ku.dk/traditionaltextilecraft/keynote_speakers/presentations/Anna_ Karatzani.pdf).

26 Our preliminary conclusions about the metal threads from the embroidery had suggested that they could be identified as so-called "Cyprus gold" or organic metal threads, which are made by gilding an organic material, such as leather, parchment, or paper, then 


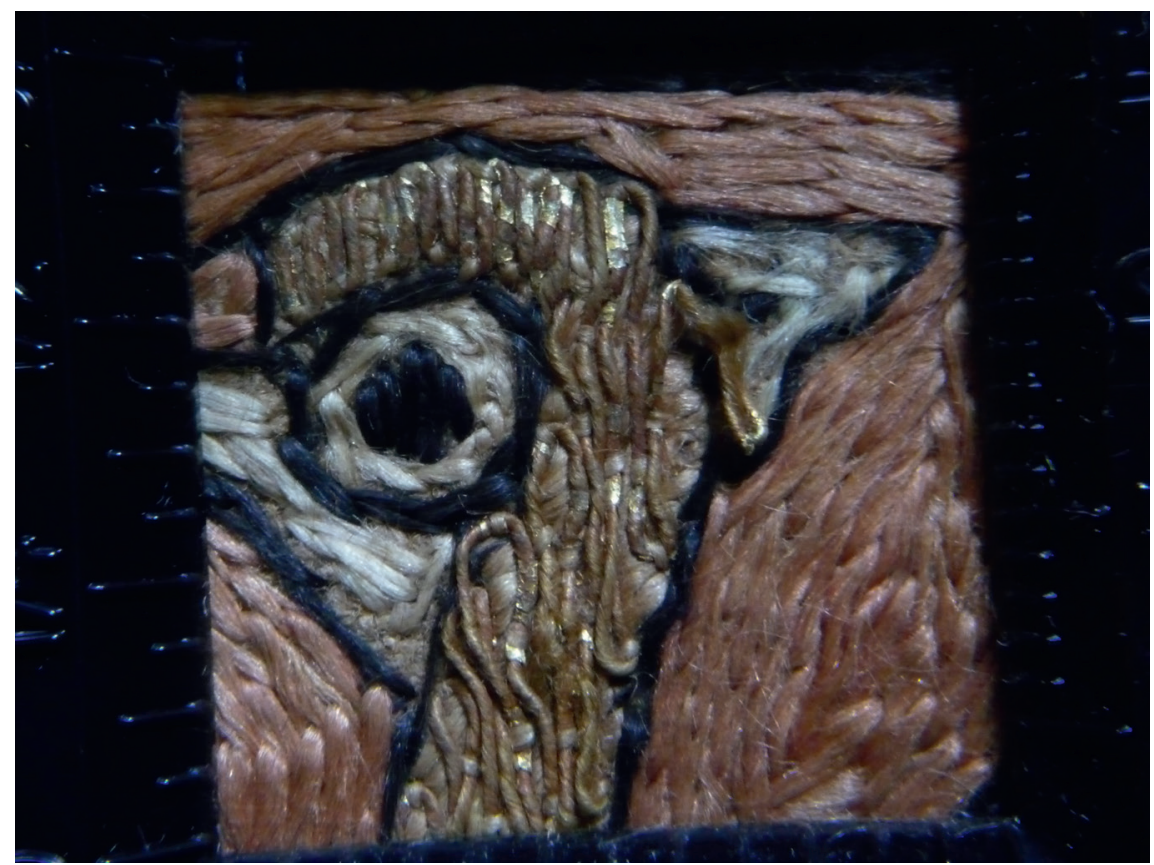

FIGURE 4 Detail of the embroidery (no. 2) with gold metal threads, scale 1,5 cms PHOTO: AUTHOR

sheet wrapped around a silk thread (Fig. 4). However, after detailed review of the photos and our preliminary analysis, we identified all the metal threads in the embroidered textile as being made from a flat metal sheet, without the use of an organic material base, wrapped around a silk thread (Fig. 5). This type of metal thread is very unusual for such an early chronology (discussed below), but threads similar to these have been recognized in some Fatimid textiles at the Royal Ontario Museum; ${ }^{27}$ we are now awaiting confirmation of their relationship through further technical analyses.

The type of metal threads made with strips of metal alone is generally considered a twelfth-century development, for which we have written sources that

cutting it into narrow strips to wrap around a silk or linen thread (see Járó, "Gold Embroidery," 50). These threads are common in early tapestries and embroideries from Iberia, Egypt, and Sicily. After a second review of the macro photographs, however, it seems that no organic material (leather or parchment) was used. We are waiting for the SEM (scanning electronic microscopy) images and results to confirm the exact materials used in the textiles at San Isidoro.

27 I thank J. Poulin of the Canadian Conservation Institute for drawing my attention to this type of metal thread during my visit to the Royal Ontario Museum in November 2017. 


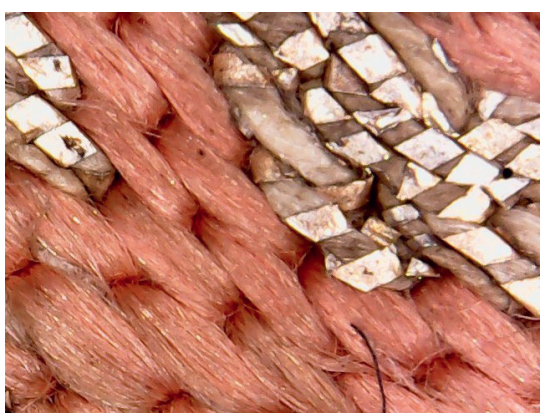

FIGURE 5

Detail of the gilt-silver metal thread of tablet weave no. 13

PHOTO: AUTHOR

explain the complex process involved in creating these threads. ${ }^{28}$ In our case they consist of gilt-silver metal strips wrapped around a yellow silk thread, as can be seen on the tablet-woven stole and maniple set, as well as the small textile-covered container (see Fig. 8; Table, nos. 12-14). This manner of producing metal threads appears from the twelfth century onwards, and it was common in the fourteenth and fifteenth centuries, just at the time that organic metal threads disappeared.

The other raw materials used in all but one of the San Isidoro textiles are the dyes to color the fibers. We were able to document that these textiles were dyed before spinning, which can be detected by close observation of the threads. When threads are dyed, some parts remain undyed or are left with a lighter color. We have assumed that the colors were obtained from naturals dyes made from plants or animals (insects or molluscs) as they were the only sources of dyes in the medieval period. ${ }^{29}$

The current colors visible on the textiles need to be taken with a degree of caution; to avoid misunderstandings about the different colors and hues, we have used descriptors in the basic range: red, blue, green, yellow, brown, pink, black, orange, and violet. This precaution is because natural dyes fade as time passes. The best examples of this phenomenon are textiles no. 11 (see Figs. 3a-b) and no. 7. The former, which at first sight should apparently be classified as bicolored (blue and cream or white), is, in fact, made up of pink, green, yellow, and blue threads; these are still visible on the reverse, which has been protected from exposure to light. The second textile has the same issue: despite

28 Ana Cabrera Lafuente, "Materias preciosas textiles: el caso del bordado con posible escena de Pentecostés del Museo Nacional de Artes Decorativas," Anales de Historia del Arte 21 (2014): 27-37.

29 The complete results of the dyes analyses will be published by Laura Rodríguez Peinado. See note 9 . 


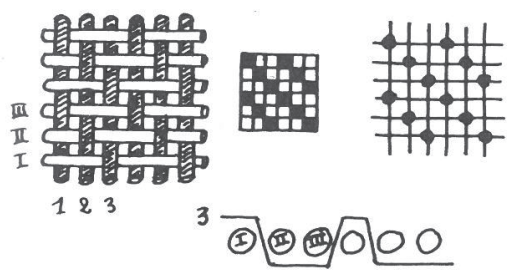

FIGURE 6

Diagram of a twill 2/1 (2 wefts or horizontal thread cross over one warp or longitudinal thread) and the different types of diagrams used to represent the weaves.

PUBLISHED IN CIETA TECHNICAL NOTES

its seemingly bicolored surface, the threads were originally green, blue, and cream. This issue of fading is particularly evident in yellows, greens, and blues.

Color is an essential aspect of the textiles, not only due to the cost of the dyes but also for its significance, as is the case with purple. This color related to imperial and royal garments has a long history, especially from the Roman Empire and the Middle Ages. One of the San Isidoro fragments has a brilliant violet color (Table 1, no. 5); we had hoped that dye analysis would reveal it to be "true purple," that is, made from murex shellfish, but the results showed instead a combination of plant dyes: blue from indigotine plants, such as indigo or woad, ${ }^{30}$ and red from madder. ${ }^{31}$

To a large extent we were able to identify the textile weaves, most of which are compound weaves, through a thread by thread study. ${ }^{32}$ This consists first of differentiating the warps (longitudinal and fixed threads in the length of the fabric) from the wefts (transverse threads that cross over and under the warps in the width of fabric) (Fig. 6). ${ }^{33}$ Second, the twist or spinning direction of the warps and wefts is documented and defined as either "Z" or "S" in direction, that is, either clockwise or counter-clockwise during the spinning process, as a defining characteristic of textiles that helps to identify geographical traditions (see Fig. 2b). Finally, we studied how the warps and wefts work together to create the pattern.

30 Indigo and woad share the main component of indigotine; as yet a differentiation between these two plants is not possible.

31 This combination of plant dyes has been documented in Byzantine silks; see Muthesius, "Essential Processes," 167.

32 Further study is needed to confirm certain technical questions that arose after the on-site campaign in March 2017. We hope to carry this out in the near future.

33 The textile terms used in this article follow the terminology of the CIETA (Centre International d'Etude des Tissus Anciens) with a multilingual dictionary. Other resources are Gale Owen-Crocker, Elizabeth Coatsworth, and Maria Hayward, Encyclopedia of Medieval Dress and Textiles of the British Isles, c. 450-1450 (Leiden: Brill, 2012) and Annemarie SeilerBaldinger, Textiles. A Classification of Techniques (Bathurst: Crawford House Press, 1994). See also Cabrera Lafuente, "Materias preciosas textiles." 


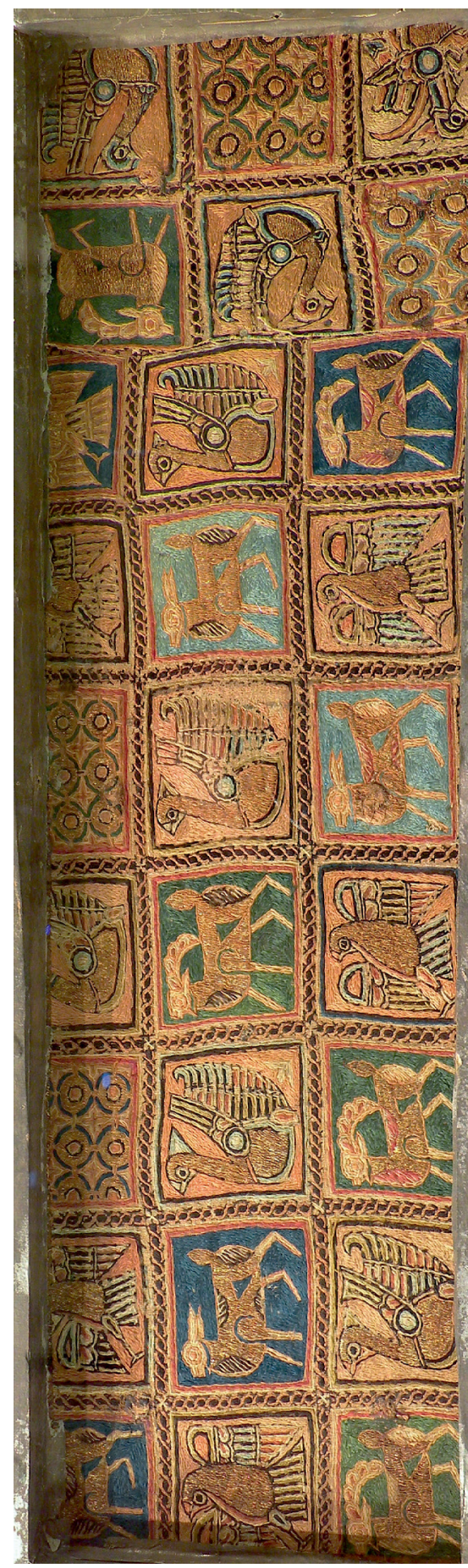

 
Compound textiles, such as most of those at San Isidoro, have two sets of warps (that is, lengthwise threads), one for the ground, usually hidden beneath the textile surface, and a second for binding the patterning wefts. Compound textiles have also at least two sets of wefts, one for the ground and one or more for the decoration, known as patterning wefts. In general, compound weaves from this period were the products of invention by Chinese weavers. The first compound weaves arrived in the Mediterranean basin in Late Antiquity, and they have been found in the necropolises of Egypt and in archaeological sites of the Near East. A later date saw the development of the lampas weave, discussed below, but its origin is still an open question. ${ }^{34}$

At San Isidoro, we have identified seven of the textiles as samites, also known as compound twills, ${ }^{35}$ with two to four wefts (Table 1, nos. 1, 3, 5, 6, 8, 9, 10). The name samite has a Greek origin, from hexamitoi or six threads, the minimum number of threads for this weave. Despite its Chinese roots, there is one modification that helps to differentiate Chinese from Mediterranean samites. Initially, the Chinese fabrics are warp-faced compound-twills, in which the warp threads are more visible on the front side of the textile; by contrast the Near Eastern and Mediterranean examples, including the textiles studied here, are weft-faced. According to Otavski, the advantages of this innovation, which appeared around the seventh century, are the reduced number of warps threads needed and the labor-saving system of cords to produce the pattern. ${ }^{36}$

One of the textiles at San Isidoro-that with a motif of stars worked in cream and green silk threads - has a geometrical design that sets it apart from the rest of the textile decorations (no. 10). Despite its plain pattern, the weave is a complex one: in the entire collection, this is the only double-faced samite, a cloth meant to be seen from both front and back. This textile shows the high technical level of a workshop that is capable of developing different solutions using the same weave, depending on the primary function of the fabric.

34 Its origins, whether Western or Eastern, have been studied by Sophie Desrosiers, Soieries et autres textiles de l'Antiquité auXVI esiècle (Paris: Reunion des Musees Nationaux, 2004), 14-28, and Mackie, Symbols of Power, 148-151. While Desrosiers stated that further study was required on the weave, noting the possibility of a Western Mediterranean origin, Mackie claimed that the lampas weave was of Eastern provenance. A third suggestion was made by Phipps, who added Iberia as a place in which lampas was first developed. Elena Phipps, Looking at Textiles: A Guide to Technical Terms (Los Angeles, CA: J. Paul Getty Museum, 2011), 47 .

35 As the name indicates it is a derivation of twill, which is based on a unit of three or more picks (individual wefts) that pass through two or more adjacent ends (individual warps) and under them, forming a pattern of diagonal lines.

${ }_{3} 6$ Karel Otavski and Anne Wardwell, Mittelalterliche Textilien. II. Zwischen Europa und China (Riggisberg: Abegg-Stiftung, 2011), 329. 


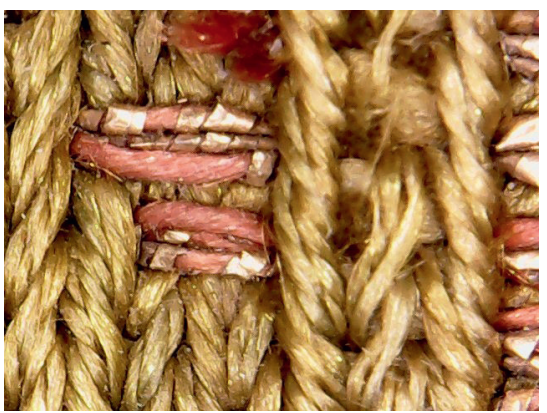

FIGURE 8

Detail of the re-twisted warps from the maniple (no. 13).

PHOTO: AUTHOR

The second type of compound weave found in some of the textiles at San Isidoro is known as lampas, in which the warps appear on the front side of the textile (nos. 7,8 , and possibly 11). One feature of this weave is that it juxtaposes two faces: the warp-faced weave for the ground and a weft-faced weave for the decorative patterning. ${ }^{37}$ One of these lampas (no. 8) has a notable additional feature that can be seen in the surviving selvedge, or weft border: it is formed by three cords of cellulosic threads, possibly linen that helps us to suggest a possible place of production (see Fig. 2a).

Standing out even among the remarkable textiles in this collection, the embroidery now lining the lid of the Arca de San Isidoro is truly extraordinary, in fact, unique (see Figs. 4, 5, and 7; Table 1, no. 2). The decoration is worked in freestyle embroidery, with silk and metal threads, on a background of linen tabby or plain weave. Certain of the animals, such as the eagles and wild goats, are drawn with a sense of naturalistic treatment, unlike the peacocks and the possible phoenix; the partial nature of the latter makes a definitive identification difficult. For the ground of each square, the threads are worked from the center outwards, creating an optical effect of perspective.

The final technique seen in three of the textiles at San Isidoro-the stole and maniple set, and the textile covering a bone or wooden cylindrical box-is a tablet-weave, with three patterning wefts (nos. 12, 13, and 14). To create this weave, known since prehistory, the warps are laid out through tablets or cards pierced by holes, and the weaving is then done through the rotation of the tablets, which gives rise to the characteristic twist of the warp threads with the pass of the shuttle (Fig. 8). ${ }^{38}$ This weave was used especially for stoles and maniples, as well as the bands and ribbons that decorated the borders of robes and bags. It was produced by a significant number of workshops in medieval

37 Phipps, Looking at Textiles, 47.

38 Nancy Spies, Ecclesiastical Pomp and Aristocratic Circumstance: A Thousand Years of Brocaded Tabletwoven Bands (Jarrettsville, Maryland: Arelate Studio, 2000), 108-110, figure 113. 
Europe and was common on the continent, the British Islands, Sicily, and Iberia.

One further method of analyzing weaves that has been carried out for the pieces at San Isidoro is that concerning thread density, or counting by centimeter, which gives information about the quality of the textile. This important fact is related to the weave and thread thickness; the textiles in our study range from approximately 45 to 90 threads per centimeter, with the lampas having the highest number of threads, followed by the samites. We noted that most of the wefts of these fabrics run from one side to the other of the textile's width; this technical feature increases the number of silk threads and therefore the overall cost of the cloth.

To contextualize the textiles at San Isidoro, we first looked to other textiles whose chronologies are certain, thanks to their well-known contexts such as burials, documented church treasuries, archaeological sites, or radiocarbon dating. Further, we searched for artworks with similar decoration, especially but not exclusively textiles, while keeping in mind the features of fibers and weave. The most closely related pieces we found in other collections are summarized for each entry in Table 1.

We were fortunate to be able to carry out the first-ever carbon-14 analysis on four of the textiles at San Isidoro, the two lining the Arca de San Isidoro (nos. 1 and 2), along with fragments no. 7 and 10. These were deemed the most suitable for radiocarbon testing for several reasons: their loose threads meant easy access for sampling without risk of damaging the whole; there was no sign of organic contamination that could affect the results of the testing; and the lack of well-dated comparative examples meant that chronology would be difficult to establish by other methods. The rest of the textiles in this collection were not apt for precise spot sampling due to the intervention carried for the exhibition in 2000, in which the fragments were sewn onto supporting grounds for display.

The results of radiocarbon analysis give us the first solid idea of the time frame of these textiles, which ranges across four centuries, from the ninth to the thirteenth. These dates have been used as a starting point to contextualize the other fabrics from San Isidoro and to begin to re-evaluate them in light of our new data. Both radiocarbon dates and the comparison with works in other collections would ascribe the textiles at San Isidoro to three chronological groups: the early ones from the ninth to tenth centuries; a second group in 
the eleventh century; and a third in the twelfth to early thirteenth centuries (see Table 1).

The early textiles account for most of the samites or compound-twills, as well as the embroidery and one early lampas (no. 7). Our samites are comparable to textiles from other European church treasuries, notably Sens (France) ${ }^{39}$ and St. Servatius in Maastricht (The Netherlands), ${ }^{40}$ apart from those held in museums and collections. The textiles related to our fragments are summarized in the Table, some of which are highlighted below.

The textiles lining the San Isidoro casket belong to the oldest group. In the case of no. 1, this weaving decorated with a pattern of pearl medallions and garlands pertains to an identified group of early silks. Although the pearl medallion pattern is very well-known, of Sassanian origin, ${ }^{41}$ few of the existing examples share this same composition of completely separate medallions. Surprisingly, the closest parallel is in the Cathedral of Leon (Fig. 9), with another closely related example at the Musée de Cluny (Paris), along with the Marwan silk (now in several collections).$^{42}$ These textiles have been classified as the production of Central Asian workshops, ${ }^{43}$ and some have been radiocarbon dated with similar chronologies to our textile, ranging from the end of the eighth century through the third quarter of the tenth. ${ }^{44}$ It is therefore of real significance that

39 Eugene Chartraire, Les tissues anciens du trésor de la Cathedrale de Sens (Paris: Honoré Champion, 1911). I offer my thanks to Dorothée Censier and Virginie Garret of Musees CEREP, Ville de Sens for their help with the study of the textiles in October 2017.

The medieval textiles collection at the Basilica of Saint Servatius is one of the most important in Europe, with a large number of woven silks from the seventh century onwards. See Annemarie Stauffer, Die mittelalterlichen Textilien von St. Servatius in Maastricht (Riggisberg: Abegg-Stiftung, 1991).

41 Dorothy Shepherd and Walter Henning, "Zandanījī Identified?" in Aus der Welt der islamischen Kunst: Festschrift für Ernst Kühnel zum 75. Geburtstag am 26.10.1957 (Berlin: Gebr. Mann, 1959), 15-40; Regula Schorta, ed., Central Asian Textiles and Their Contexts in the Early Middle Ages (Riggisberg: Abegg-Stiftung, 2006).

42 Several fragments of one large silk have been dated thanks to a Kufic inscription naming the caliph Marwan II, reigned 744-750. See Mariam Rosser-Owen and Mina Moritau, "Marwan Silk Fragments," in Byzantium and Islam. Age of Transition, ed. Helen Evans (New York: Metropolitan Museum of New York, 2012), 238-240.

43 Regula Schorta, "Central Asian Silks in the East and West during the Second Half of the First Millennium," in Oriental Silks in Medieval Europe, ed. Juliane von Fircks and Regula Schorta (Riggisberg: Abegg-Stiftung, 2016), 47-63.

44 Nicholas Sims-Williams and Gregory Khan, "Zandanīī Misidentified," Bulletin of the Asia Institute 22 (2011): 207-213. Some of them are complete, giving us an idea of size and functionality as hangings, for example, the St. Mengold shroud (Notre-Dame Church Treasury at Huy, Belgium) or the silk textile at the Treasury of Liège Cathedral. See Table 1 for further references. 


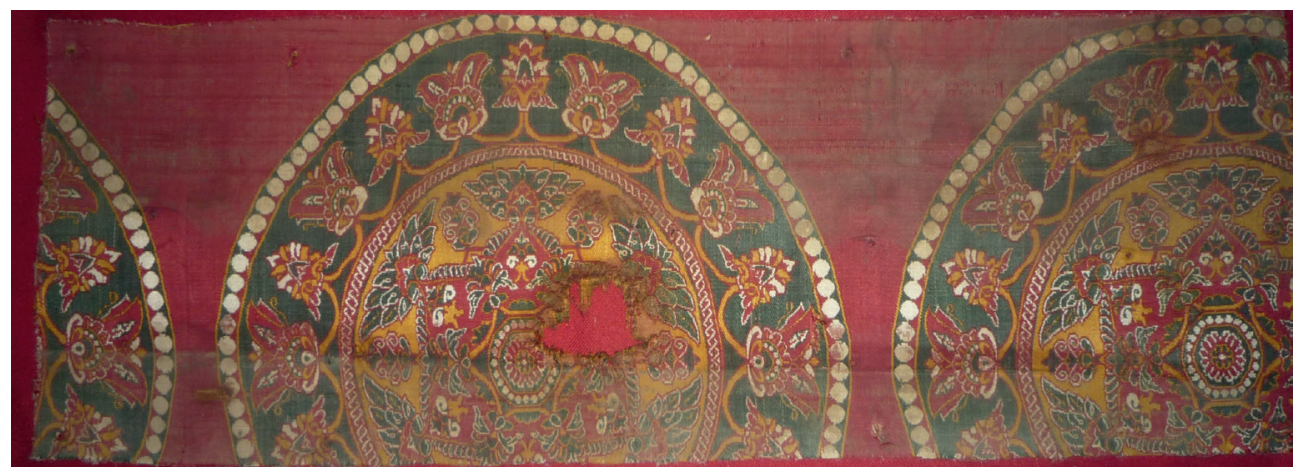

FIGURE 9 Silk samite from León Cathedral PHOTO: AUTHOR

the dyes analysis for our textile has shown that kermes was used for the bright red color; this dye is usually associated with Andalusi and Iberian silks. ${ }^{45}$ This result is similar to that of another samite silk dyed with kermes, which has previously been classified as Central Asian and fragments of which are held by the Royal Museum of Brussels and the Victoria and Albert Museum in London. ${ }^{46}$ Whether Central Asian or Iberian, it is clear that kermes alone is not enough to identify the location of the textile workshop; further dyes analysis and comparisons with other documented textiles are therefore needed to support or discard Central Asia as the place of production of the Isidoran silk.

The remarkable embroidery lining the lid of the Arca de San Isidoro (no. 2) has some features that may help us to identify its possible place of production. An unexpectedly early chronology was established by carbon-14 testing of the linen tabby used for the background, ${ }^{47}$ locating this textile between the end of the ninth and the beginning of the eleventh centuries; we can therefore confidently consider the embroidery a tenth-century work. For this extraordinary textile, we have identified a few visual parallels in other media for the

45 Ana Cabrera Lafuente, "Caracterización de las producciones textiles en Al-Andalus (siglos IX al XIV): estudios sobre tintes," in Tejer y vestir: De la Antigüedad al Islam, ed. Manuela Marín (Madrid: Consejo Superior de Investigationes Científicas, 2001), 395-415; María Dolores Gayo and Ángela Arteaga, "Análisis de colorantes de un grupo de tejidos hispano-musulmanes", in Bienes Culturales 5 (2005), 123-147 http://es.calameo.com/ read/oooo75335d3od779doea7.

46 Mieke van Raemdock, En Harmonie. Art du monde Islamique au Musée du Cinquantenaire (Brussels: Racine, 2015), 228. Kermes is also found in Byzantine silks of the early period, and it was restricted to the royal workshops. See Leslie Brubaker, "The Elephant and the Ark: Cultural and Material Interchange across the Mediterranean in the 8th and 9th Centuries," Dumbarton Oaks Papers 58 (2004), 175-195, at 91, note 86.

47 We decided to sample the linen ground rather than the silk threads because of the possibility that the embroidery might have been restored or re-embroidered in the past. 
pattern of animals within a squared framework (see Table 1). A similar design can be found, for example, on a sculpted pulpit brought from Constantinople to Ravenna in the later sixth century and on marble panels from the Old Cathedral of Sorrento, dated to the late tenth and early eleventh centuries. ${ }^{48}$ None of them, however, has a close connection with the embroidery, although certain Fatimid tapestries and some embroideries from the Seljuq period have some resemblance. ${ }^{49}$ The parallels would suggest for our embroidery a Near Eastern workshop, ${ }^{50}$ but this is still an open question, due to the paucity of medieval embroideries as comparative material. The design on the piece is altogether unlike the contemporaneous embroideries produced in European workshops, whether Anglo-Saxon, Italian, French, or German. Moreover, the metal threads are not from European or Anglo-Saxon workshops, which generally used linen as the core for metal threads, by contrast with the silk used here.

The rest of the fragments from the early group at San Isidoro could have originated from Byzantine workshops due to the samite weave as well as patterns and colors characteristic of workshops from this Eastern Mediterranean area, such as the heart-shaped leaves and the bird (possibly a peacock) of textile no. 3 , and the scrolls and color of no. 5 (see Table 1 for detailed references). Textile no. 5 is similar to fabrics held at other ecclesiastical sites in Iberia, among them the Cathedral of Urgel and the monastic church at Covarrubias. ${ }^{51}$

Among the samites, one fragmentary textile (no. 4) presents particular difficulties for establishing its workshop. The partial decoration is hard to identify; we can make out an animal's tail, branches that terminate in snake heads, and a border with wings. The tail has similar patterns to a now lost fragment from the reliquary casket of Santa Eulalia at the Cathedral of Oviedo (Fig. 10). The depiction of snake heads recalls that on a ninth- to tenth-century silk samite from Saint Servatius (Maastricht).52 The Servatian fragment has been considered of either Byzantine or Iberian origin, depending on the scholar; the

48 Emma May Edwards, "Reception and Reorientation: The Impact of Internationally Traded Objects in Italian Art and Architecture (950-1150)," PhD diss., Courtauld Institute of Art, University of London, 2016, 99-100, figs. 1.35-37. I thank Dr Edwards for drawing my attention to these artworks.

49 As some of the animals and motifs (Mackie, Symbols of Power, 157).

5o As was also suggested by Manuel Gómez-Moreno, "El arca de las reliquias de San Isidoro," Archivo Español de Arte y Arqueología 15 (1932): 205-212, esp. 209-210.

$5^{1} \quad$ Laia Monge, "Els teixits produïts i comercializats al mediterrani: el cas de teixits bizantins a la Seu d'Urgell," Síntesi. Quaderns dels Seminaris de Besalú, 2 (2014): 55-74. I thank M. J. Feliciano and L. Rodríguez for drawing my attention to the Covarrubias fragment.

$5^{2}$ Identified as a fragment of a bag from an Iberian workshop of the tenth century. See Dominique Cardon, Fils renoués. Trésors textiles du Moyen-âge en Languedoc-Roussillon (Carcasonne: Musée des Beaux-Arts, 1993), 116, no. 35. 


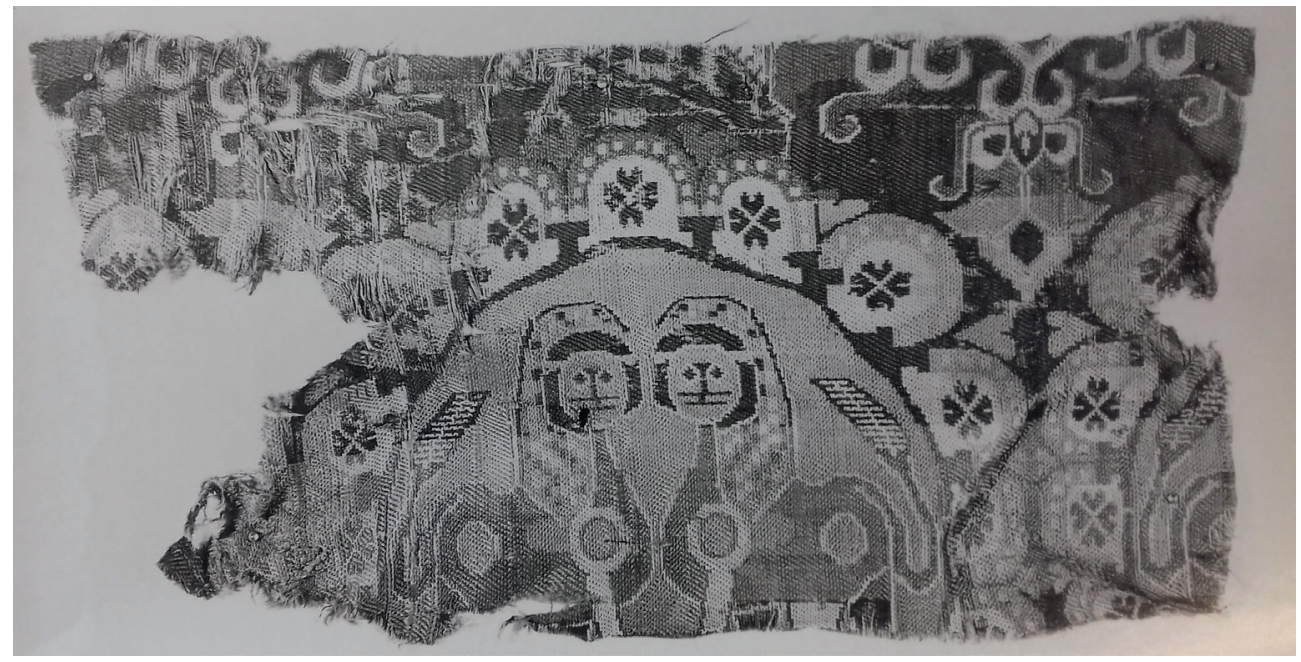

FIGURE 10 Textile (now lost), originally lined Santa Eulalia's casket from the Cathedral of Oviedo

PHOTO: ARXIU MÁS

reason for the latter possibility, according to Stauffer, is its similarity to illuminations in Iberian manuscripts..$^{53}$ However, the Isidoran fabric has metal threads not seen in any of the parallels, and the colors and weave features are different from the Iberian samites. ${ }^{54}$

This early group also includes a lampas, another remarkable piece, unique among Iberian textile collections, which has, unfortunately, been cut into six fragments (Fig. 11; no. 7). The rich decoration features interlinked pearl bands around medallions with figures as well as epigraphic bands in Kufic script ${ }^{55}$ alternating with star-shaped medallions and small dragons. Both male and female figures are depicted; 56 the former wears a kaftan and holds a short dagger in his hand, with a lion positioned behind him. The female figure, wearing an elaborate headdress, rides a horse side-saddle and holds a flowering branch in her left hand. The composition, which fills the surface, may be linked to Buyid and early Seljuq workshops, ${ }^{57}$ but such an early chronology raises questions about the beginnings of lampas weave. Further studies and a careful restoration are urgently needed.

53 Stauffer, Die mittelalterlichen Textilien von St. Servatius, 128-129.

54 For the features of Iberian samites, see Cardon, Fils renoués, 100-101 and 106.

55 For the inscription, see the article by María Judith Feliciano in this volume.

$5^{6}$ See Figures 11 and 12 in María Judith Feliciano's contribution in this volume.

57 Mackie, Symbols of Power, 145-148. 


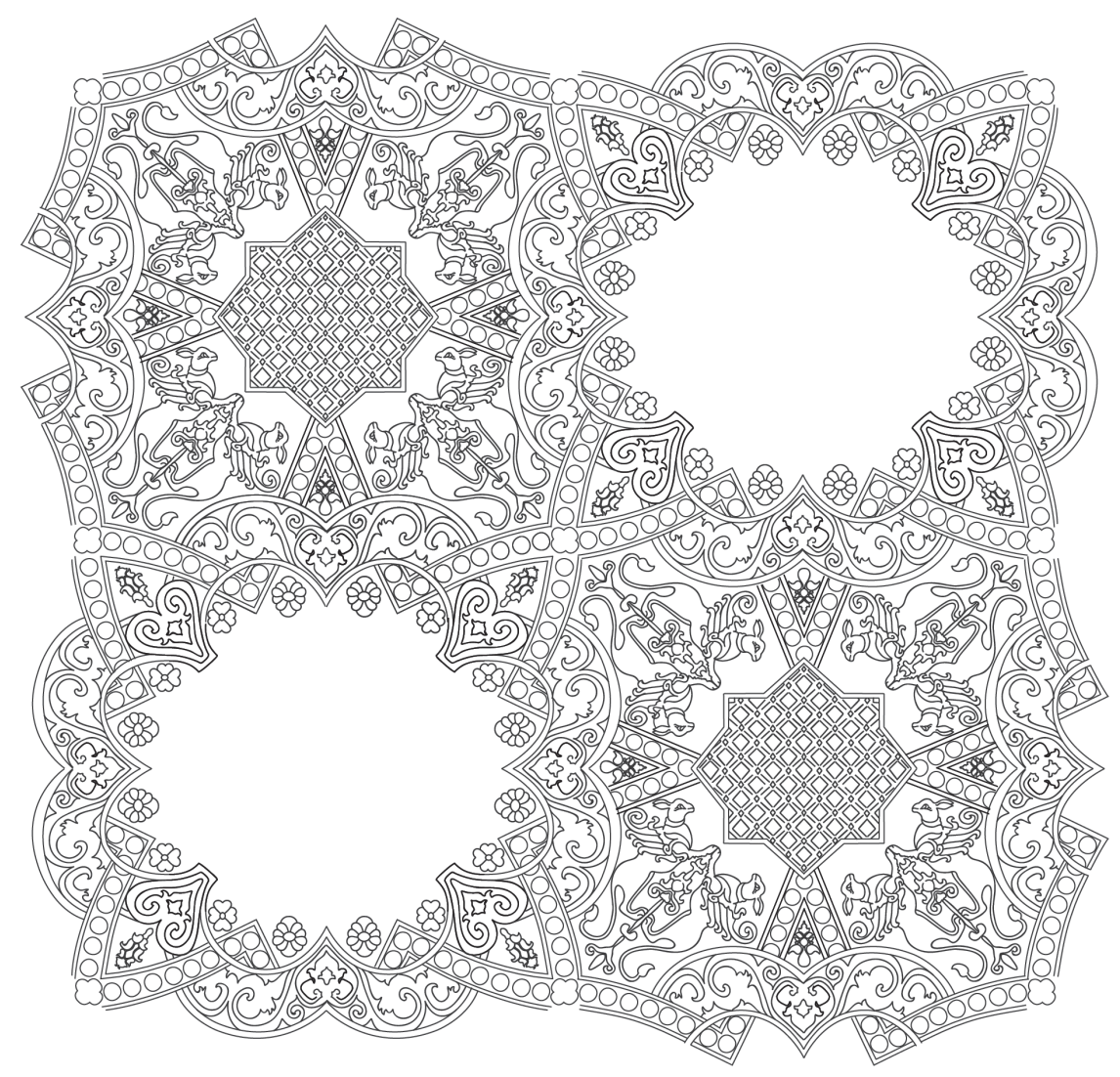

FIGURE 11 Drawing of the complex decoration of silk textile no. 7. The blank spaces represent the medallions with figures that need further photographs to be reproduced accurately.

DRAWING: AYELET SHATS

The second San Isidoro group comprises textiles nos. 8, 9, 10, and 11, which include two samites and two lampas dated from the early eleventh to early twelfth centuries. One of the samites is the textile that lines the casket of Saints Pelayo and John the Baptist (no. 9). ${ }^{58}$ The decoration is organised in bands with vine scrolls enclosing different animals (gryphons and possibly hawks), paired animals (hares on one side, and ducks and birds on the other), and

$5^{8} \quad$ For a summary of this textile, see Noemi Álvarez da Silva, El trabajo en marfil en la España del siglo XI, PhD diss., Universidad de León, 2014, 170-173. 
between them a narrow epigraphic band, ${ }^{59}$ and a wider red band, which at first sight appears to be undecorated but in fact has medallions and vegetal motifs. ${ }^{60}$ This broad red band, with its patterning known as soie incisée, or incised silk, provides a heretofore unnoticed clue to the textile's chronology. The term was coined by Martiniani-Reber to refer to a specific type of silks dated from the eleventh century onwards. ${ }^{61}$ This feature further allows us to identify the Isidoran silk with those described as khimha in Arabic (also known as kamochas in Byzantine texts or camocas in Italian). It is interesting to note that the Arabic expression "al harir al afum" (literally, one-eye silk) indicates the feature of such decoration, which sometimes is visible and others not. ${ }^{62}$

We are currently working on a reconstruction of this textile according to its patterns; these suggest that, with a width of $82 \mathrm{~cm}$, it is the widest textile in the Isidoran collection. ${ }^{63}$ The decoration is organized in bands in which the predators appear above their prey, as Jerrilynn Dodds rightly noted during our March 2017 campaign. One further detail that we observed, which may be related to the design and the loom, is that the width of one of the bands is narrower than the others (Figs. 12a-b). A similar feature (or error) has been identified in other textiles, such as the so-called Witches Pallium (Museu Episcopal de Vic) or the blue silk with double-headed eagles at San Zoilo de Carrión de los Condes, ${ }^{64}$ caused by a loom wider than usual which required two weavers to manufacture the textile.

Unfortunately, the Isidoran textile had an intervention around the year 2000, during which it was removed from the reliquary casket, "restored," lined with another fabric, and placed again in the casket. These actions precluded the sampling of fibers, testing of dyes, or analysis of carbon-14. For its chronology,

59 Dokmak and Sayed have recently read the inscription as "izz limawbdnā almalk," repeated along the band. According to the authors this is an incorrect phrasing of "izz limawlāna a almalk" (Glory to our Lord, the King). See Ahmed Dokmak and Zeinab Sayed, "Aportaciones de la epigrafía árabe en el arte románico español. Una faceta de la cultura árabeislámica medieval," Un mundo, muchas miradas 4 (2015): 115-116, note 32. For further information on the inscription see María J. Feliciano's contribution in this volume.

6o In fact, the decoration of this red band had gone unnoticed until January 2017, our first on-site visit to study the artworks of San Isidoro.

61 Marielle Martiani-Reber, Musée Historique des Tissus-Soieries sassanides, coptes et byzantines, $V^{\text {ème}}-X \mathrm{I}^{\mathrm{e} m e}$ siècles (Paris: Réunion des musées nationaux, 1986), 118-123.

62 Lombard, Les tissus dans le monde musulman, 242-243.

63 May, Silk Textiles of Spain, 27, also noted this an unusual width.

64 Pilar Borrego, Silvia Saladrigas, and Miguel Ángel Andrés-Toledo, "Technical and Symbolic Study of Two Complete Mediaeval Cloths Found in Carrión de los Condes, Spain," in Purpureae Vestes, v, Textiles, Basketry and Dyes in the Ancient Mediterranean World, ed. Jónatan Ortiz, Carmen Alfaro, Luis Turell, and Julia Martínez (Valencia: Universitat de València, 2016), 163-170. 
therefore, we depend on the red incised band to date this textile from the mideleventh to mid-twelfth centuries.

The so-called Baghdad silk (no. 4) is one of the best-known textiles in the collection, due to the presence of a Kufic inscription that names this city as the place it was produced. The inscription reads: "Blessing from God and prosperity" (in the upper circle) and "to its owner Abu Nasr. Made in Baghdad" (in the lower circle). ${ }^{65}$ Its decoration compares closely to other silk textiles with griffins and birds, such as the shroud of St. Potentian at Sens Cathedral, ${ }^{66}$ the Syon silk, and the elephant silks from Aachen ${ }^{67}$ and from the Sancta Sanctorum of Rome, all of them considered to be from the Near East or Central Asia. However, our textile has certain features that suggest another option. First, the selvedge of three linen cords is similar to those from Iberian workshops (see Fig. 2a). Second, the lampas weave has technical characteristics documented in lampas from Andalusi workshops: 68 the grouping of the main warp-end pairs for the warp step seems to coincide with the grouping of the same threads for the tabby ground. ${ }^{69}$ And finally, the yellow wefts used for the heads and claws of the lions, along with the inter-linking medallions, could be an imitation of the metal threads that appear in some of the eleventh- and twelfth-century textiles from Iberian workshops, such as those at Santa Librada. ${ }^{70}$ These elements together allow us to suggest that the fragment is from an eleventhcentury fabric possibly produced in an Andalusi workshop, despite the inscription that boldly states otherwise.

In contrast to the so-called Baghdad silk, textile fragment no. 11 still has many unanswered questions. It is decorated with the head of a fierce animal that bares its teeth within an elaborate medallion made up of vegetal and decorative motifs, along with griffins in roundels. The large animal's head may

65 See Kendrick and Guest, "A Silk Fabric Woven in Baghdad," 267. As Feliciano has noted the name in the inscription was wrongly read by Guest. The name cited is Abu Bakr (see Maria Judith Feliciano's contribution in this volume).

66 Desrosiers, Soieries et autres textiles, 242-243.

67 Kendrick and Guest, "A Silk Fabric Woven in Baghdad," 267.

68 To confirm this feature, however, we would need to make a close study of the textile from both sides, which is not currently possible as the back is lined, leaving visible only a small window of approx. 15 × $15 \mathrm{~mm}$. Karel Otavsky, "Remarques techniques concernant des tissus égyptiennes, perses et ibériques de la Fondation Abegg," in Islamische Textilkunst des Mittelalters: Aktuelle Probleme (Riggisberg: Abegg-Stiftung, 1997), 147-156.

69 I thank Dr. R. Schorta for drawing my attention to this possibility.

70 Karel Otavski and Muhammad 'Abbas, Mittelalterliche Textilien. Ägypten, Persien und Mesopotamien. Spanien und Nordafrika (Riggisberg: Abegg-Stiftung, 1995), 145-16o. 

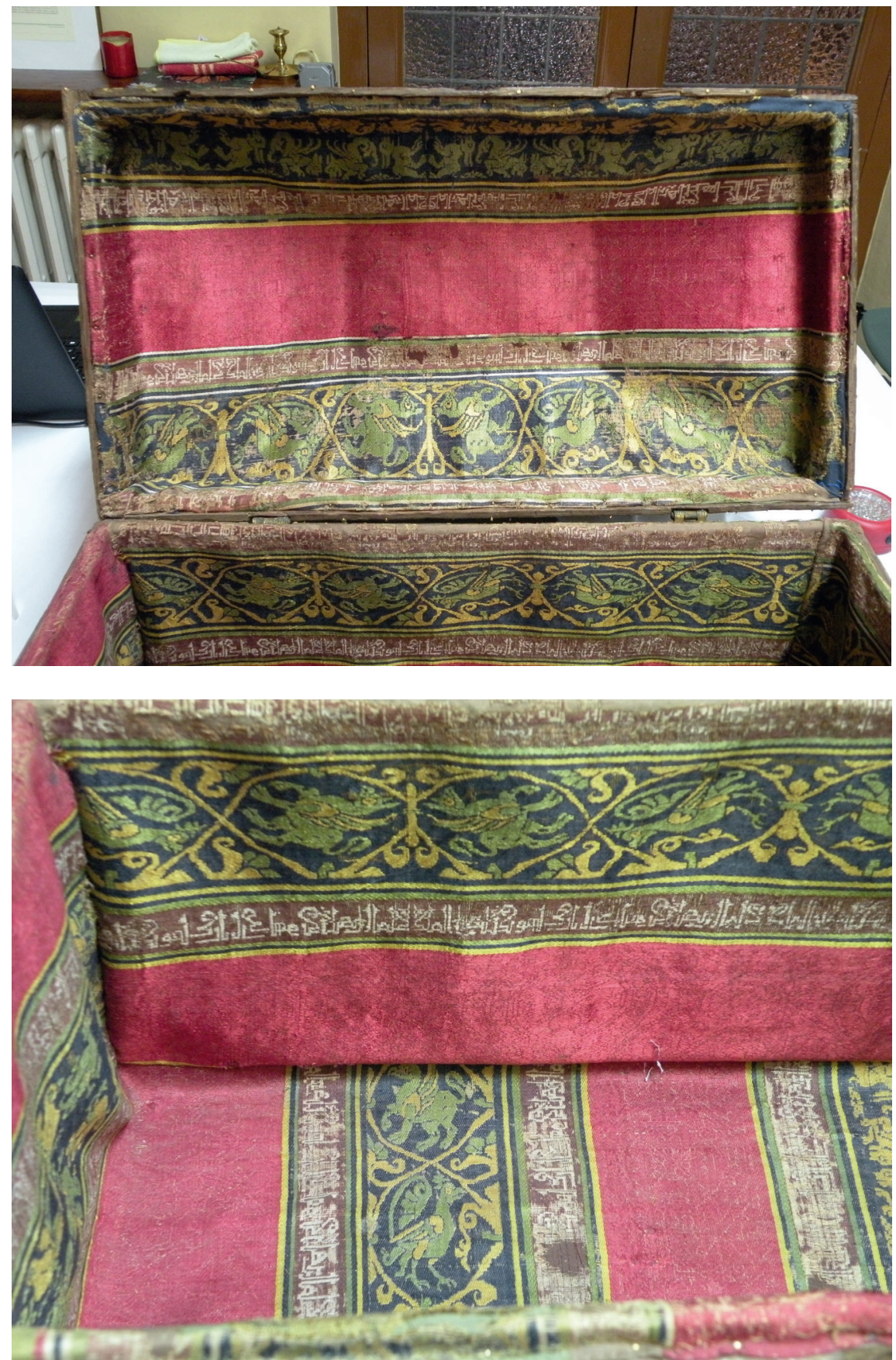

FIGURES 12A AND 12B

Detail of the silk samite that lines the casket of Saints Pelayo and John the Baptist (no. 9). One band has oval rather than round medallions. PHOTOS: AUTHOR AND THERESE MARTIN 
perhaps be identified as that of a simurgh (or senmurv). ${ }^{71}$ During the early Islamic period this mythical creature combining a lion and an eagle appears on textiles (see Table 1). However, the use of the simurgh would seem to indicate for this piece an early chronology that does not agree with its weave, which is a lampas. Further research is needed to confirm the weave features of this textile.

Finally, the third group of textiles at San Isidoro dates from the late twelfth to early thirteenth century (nos. 12, 13, and 14). They are all tablet weaves and have many known technical parallels, most of them from England, Germany, and other areas of continental Europe. Sicily and Spain, according to Spies, have a "distinctive style" related to geometrical patterns and heraldry motifs. ${ }^{72}$ The epigraphical decoration seen on the stole and maniple is not common. According to Spies, this type of brocaded tablet-weave ${ }^{73}$ dates from the eleventh to thirteenth centuries. ${ }^{74}$

Our research demonstrates that the overall chronological framework of the textiles in the treasury of San Isidoro de León can be established between the ninth century and the turn of the thirteenth, with pieces produced in a wide variety of workshops from Central Asia, the Near East, Byzantium, and different parts of Europe; curiously, the least common here are those originating in Iberian workshops. This array of textile fragments and liturgical vestments is a prime example, among Iberian textile collections, of the extent of trade and wide-ranging communications during the central Middle Ages. The early date of some of the fragments, prior to San Isidoro's "1063 charter," leads

71 For this creature and its depiction in textiles see Van Raemdock, En Harmonie, 30-35. There is a silk samite with a simurgh that has been dated by carbon-14 to 890-1002 AD. For its name, see Matteo Compareti, "The So-Called Senmurv in Iranian Art: A Reconsideration of an Old Theory," in Loquentes linguis. Studi Linguistici e Orientali in onore di Fabrizio A. Pennacchietti, ed. P. G. Borbone, A. Mengozzi, and M. Tosco (Wiesbaden: Harrassowitz Verlag, 2006), 185-200.

72 Spies, Ecclesiatical Pomp, 79-80.

73 "Brocaded" implies a decorative weft, including the metal thread. This term is often confused with "brocado," a Spanish term that means literally "decorated textile" without reference to any technical feature.

74 Spies, Ecclesiastical Pomp, 77-81. For a discussion of the stole and maniple in context, see Jitske Jasperse, "Matilda, Leonor and Joanna: The Plantagenet Sisters and the Display of Dynastic Connections through Material Culture," Journal of Medieval History 43.5 (2017): $523-547$. 
us to ask how, when, and why these textiles arrived in León. Before presenting some hypotheses, we need to look at what was happening across the medieval West with silks like these and to consider the multiple meanings of silk itself, which was held in high consideration for more than its precious nature. ${ }^{75}$ As Fricks and Schorta explain, woven silks played an important role in European culture from the end of the Antiquity to the early modern period. The high esteem for silk fabrics is documented both in a multitude of written sources and through their careful preservation in church treasuries, relic shrines, and royal, papal, and aristocratic burials. From as early as the Merovingian period these textiles came from Byzantium, Persia, Islamic Egypt, Central Asia, and Iberia. ${ }^{76}$

We would suggest that the gathering of textiles at San Isidoro was part of the "thesaurization" 77 phenomenon that included the acquisition of decorated silks at medieval Christian shrines, such as St. Servatius in Maastricht, and at royal foundations and papal and episcopal seats, among them the cathedrals of Sens, Aachen, and Bamberg. ${ }^{78}$ According to Leslie Brubaker, during the central Middle Ages there was an international court culture that shared values and appreciated the portability of high-status objects, which included textiles and metalworks. ${ }^{79}$ The possibility that the Leonese dynasty brought some textiles from the former royal capital in Oviedo needs to be taken into consideration because the oldest of these fabrics, including the embroidery and the weaving lining the Arca de San Isidoro, could have formed part of that earlier royal treasury. We should also consider the possibilities that the early textiles might have been acquired on the market in León ${ }^{80}$ or as part of diplomatic

75 Lombard, Les tissus dans le monde musulman, 197, explains that the textiles and their "thesaurization" can be compared with the "thesaurisation metallique et traites comme une veritable monnaie."

76 Fricks and Schorta, Oriental Silks, 7.

77 For church treasuries overall, see Joseph Ackley, "Re-approaching the Western Medieval Church Treasury Inventory, c. 800-1250," Journal of Art Historiography 11 (2014): 4-37.

78 The Cathedral of Saint Stephen of Sens was the seat of the Primate of Gaul. For other treasuries in Europe linked to royal houses like Chelles and St. Denis in France and Bamberg in Germany, see Maureen Miller, Clothing the Clergy. Virtue and Power in Medieval Europe, c. 800-1200 (Ithaca-London: Cornell University Press, 2014).

79 Brubaker, "The Elephant and the Ark," 177. Concerning this international culture, see Anna Contadini, "Sharing a Taste? Material Culture and Intellectual Curiosity around the Mediterranean, from the Eleventh to the Sixteenth Century," in The Renaissance and the Ottoman World, ed. Anna Contadini and Claire Norton (Abingdon: Routledge, 2013), 23-61. In relation to written sources and luxury objects, see the article by Ana Rodríguez in this volume.

80 Bernard Reilly, "Medieval Spain," in Art of Medieval Spain. AD 500-1200 (New York: Metropolitan Museum of Art, 1993), 7. The city had an important market, and Jews there were trading textiles from Byzantium, the Near East and al-Andalus, according to the sources studied by Claudio Sánchez Albornoz, Una ciudad de la España cristiana hace mil años 
gifts from Andalusi, Byzantine, or European courts after the establishment of the court in León by Ordoño II (d. 924). ${ }^{81}$

For these reasons, knowing the object's biography is important because, to quote Brubaker, "moving an object changes its meaning." ${ }^{22}$ Till now, little has been done to trace the biographies of the textiles at San Isidoro, which show evidence of heavy use, re-use, and manipulation ${ }^{83}$ from the medieval period until the most recent intervention at the turn of the twenty-first century. The fragmentary form of most of them speaks to their adaptation as linings for reliquary caskets and boxes, and as bags and relic wrappings. Some of the textiles are therefore likely to have been acquired as part of the extensive international movements of relics. ${ }^{84}$ According to Michael McCormick, the trade in relics ran from early in the fifth to sixth centuries through the late Middle Ages, showing again the importance and extension of trade routes, whether for sacred or mundane objects. ${ }^{85}$

On the manipulation of textiles, our nos. 7 and 10 serve as useful case studies. ${ }^{86}$ At some point during its long life, textile no. 7 was divided into four fragments and another one with three fragments sewn together; due to their varying states of conservation, the pieces had been taken as different textiles rather than the remnants of one large silk, as our work demonstrates. Traditionally, one section of this textile had been identified as al-Mansur's horse blanket, acquired (somehow) during his sacking of Leon in $997,{ }^{87}$ an idea that can no longer be sustained. Further, early twentieth-century photographs, possibly

(Madrid: Rialp, 2014), 41-42, notes 4-9. First published as Estampas de la vida en León hace mil años (Madrid, 1926). For the Jewish community in León, see the article by Julie Harris in this volume.

81 About this fact see Maria Judith Feliciano's article in this volume.

82 Brubaker, "The Elephant and the Ark," 175.

83 For the use and re-use of textiles and the formation (and misleading) of traditions on silks provenance, see Donald Bullough, Carolingian Renewal: Sources and Heritage (Manchester: Manchester University Press, 1991), 75, and María Judith Feliciano's contribution in this volume.

84 On this matter, see Mariam Rosser-Owen, "Islamic Objects in Christian Contexts: Relic Translation and Modes of Transfer in Medieval Iberia," Translating Cultures in the Hispanic World, special issue, Art in Translation 7.1 (2015): 39-64, and María Judith Feliciano's contribution in this volume.

85 Michael McCormick, Origins of European Economy. Communications and Commerce, AD 300-90o (Cambridge: Cambridge University Press, 2001), 283-318, map at 298.

86 For further discussion of these textiles, see the article by María Judith Feliciano in this volume.

87 Described as "a horse blanket, of blue color, decorated with Islamic motifs" in Eloy DíazJiménez, Historia del Real Monasterio Benedictino de San Claudio, de León, (Madrid: Imprenta de Ramona Velasco, 1930), 263. 


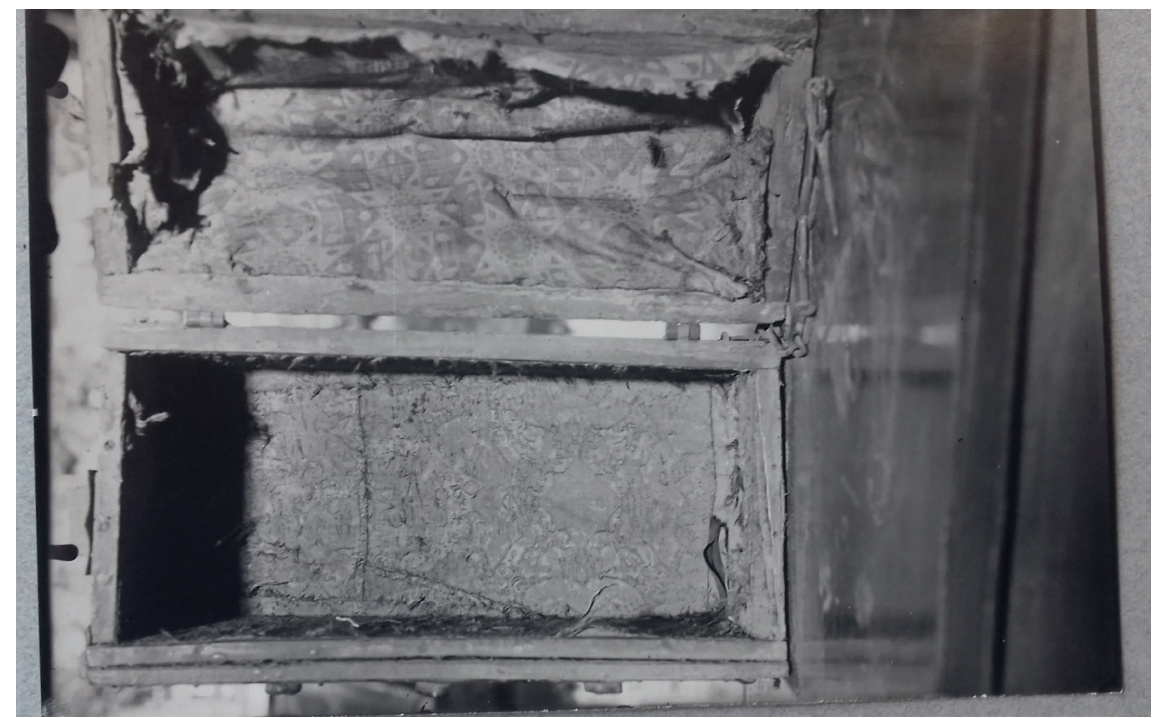

FIGURE 13 San Marcelo casket, early twentieth century, with textiles no. 7 and no. 10 still in situ

PHOTO: ARCHIVO GÓMEZ-MORENO, CSIC

related to Gómez-Moreno's research campaigns for the Catálogo Monumental, show textiles nos. 7 and 10 still in situ lining the casket of San Marcelo (Fig. 13 ). ${ }^{88}$ San Isidoro's records have no information about this provenance ${ }^{89}$ nor about the removal of the textiles from the casket, an action that stripped the objects of their context and should draw our attention to the ways in which these assemblies of fabrics have been studied from the nineteenth century onwards.

Fricks and Schorta discuss early practices of collecting and documenting textiles, noting that it was focused on the history of silk weaving, not on the function of the textiles or the context of the ensembles. This interest made it permissible to cut samples from textiles, as Franz Bock did, and to separate textiles from relics, labels, or remains, thereby losing their context. Such practices are the foundation of many textile collections in Europe and America, ${ }^{90}$ and they can also be traced to objects at San Isidoro. The textiles in the Arca de San Isidoro, for example, are fixed with modern nails, and the separate parts of the weaving lining the casket's body have been sewn together using modern

88 Photograph held by the former Archivo Fotográfico del Departamento de Historia del Arte, Consejo Superior de Investigaciones Científicas, Madrid. I thank Rosa Villalón and Pilar Martínez for their support of my research at this valuable archive.

89 A note in the museum's inventory lists no. 10 only as "textile lining from the lid of San Claudio's casket."

Fricks and Schorta, Oriental Silks, 7. 
thread. An important detail is that this fitting has been done carefully in an attempt to follow the design of the fabric, by contrast with the linings of the San Pelayo and San Marcelo caskets, in which each textile has been cut to fit the different parts of the casket. Further research is needed to establish when each of these interventions took place.

The results of our analysis demonstrate that some of the textiles in the treasury at San Isidoro, including those in the titular saint's reliquary, are older than the generally accepted chronology of mid-eleventh century, the date assigned to them in the scholarship in order to fit the "1063 charter" of King Fernando and Queen Sancha. In establishing new dates for these textiles we are cognizant of the need to strengthen research in the field of medieval textiles from Iberia overall and to apply these results to other collections that have been dated on the basis of stylistic analysis alone. At San Isidoro, one unexpected element of interest is the paucity of Iberian textiles within this heterogeneous assemble, as few as four out of a total of fourteen. The ownership of silks from a range of provenances links León with the same phenomenon at other important Christian shrines and royal seats outside Iberia, as we have noted. These data provide insight into the degree of consideration in which Iberian textiles were held in the context of the most important Christian court of the Peninsula, suggesting that local fabrics, despite being luxury items, were considered of lesser importance by the Leonese rulers than textiles from Byzantium, Central Asia, or the Near East. ${ }^{91}$ It seems that these monarchs deliberately sought textiles of exotic provenance for their most treasured objects and relics.

To support our suggestion about the intentionality behind the acquisition of textiles for San Isidoro from distant lands, this collection needs to be situated within its larger context. Further research is also needed to determine the exact number of medieval textiles from Iberia here and at other peninsular sites, putting the spotlight on the lack of a comprehensive catalogue for all these fabrics. Updated information on raw materials and weaving techniques is urgently needed, along with detailed historical documentation, including the nineteenth- and twentieth-century sources. Our preliminary work on the Isidoran collection offers a model for tracing textile provenance, a key factor in the study of historical textiles in church treasuries. This collection exemplifies the far-reaching interest of the field of textiles research for the larger area of medieval history, demonstrating that it is possible to go well beyond the possibilities and ideas envisaged in the historiography for the San Isidoro treasury up till now.

$91 \quad$ María Judith Feliciano, "Medieval Textiles in Iberia: Studies for New Approaches," in Envisioning Islamic Art and Architecture: Essays in Honor of Renata Holod, ed. D. Roxburg (Leiden: Brill, 2014), 46-65. 


\section{Acknowledgments}

Ana Cabrera's work has received funding from the European Union's Horizon 2020 Research and Innovation Programme under the Marie Skłodowska-Curie Grant Agreement No. 703711, Interwoven. Further support was provided by The Medieval Treasury across Frontiers and Generations: The Kingdom of León-Castilla in the Context of Muslim-Christian Interchange, c. 1050-1200 (PI, Therese Martin, HAR2015-68614-P), by the Princeton Institute for International and Regional Studies at Princeton University, and by Las manufacturas textiles andalusíes: caracterización y estudio interdisciplinar (PI, Laura Rodríguez Peinado, HAR2014-54918-P). 


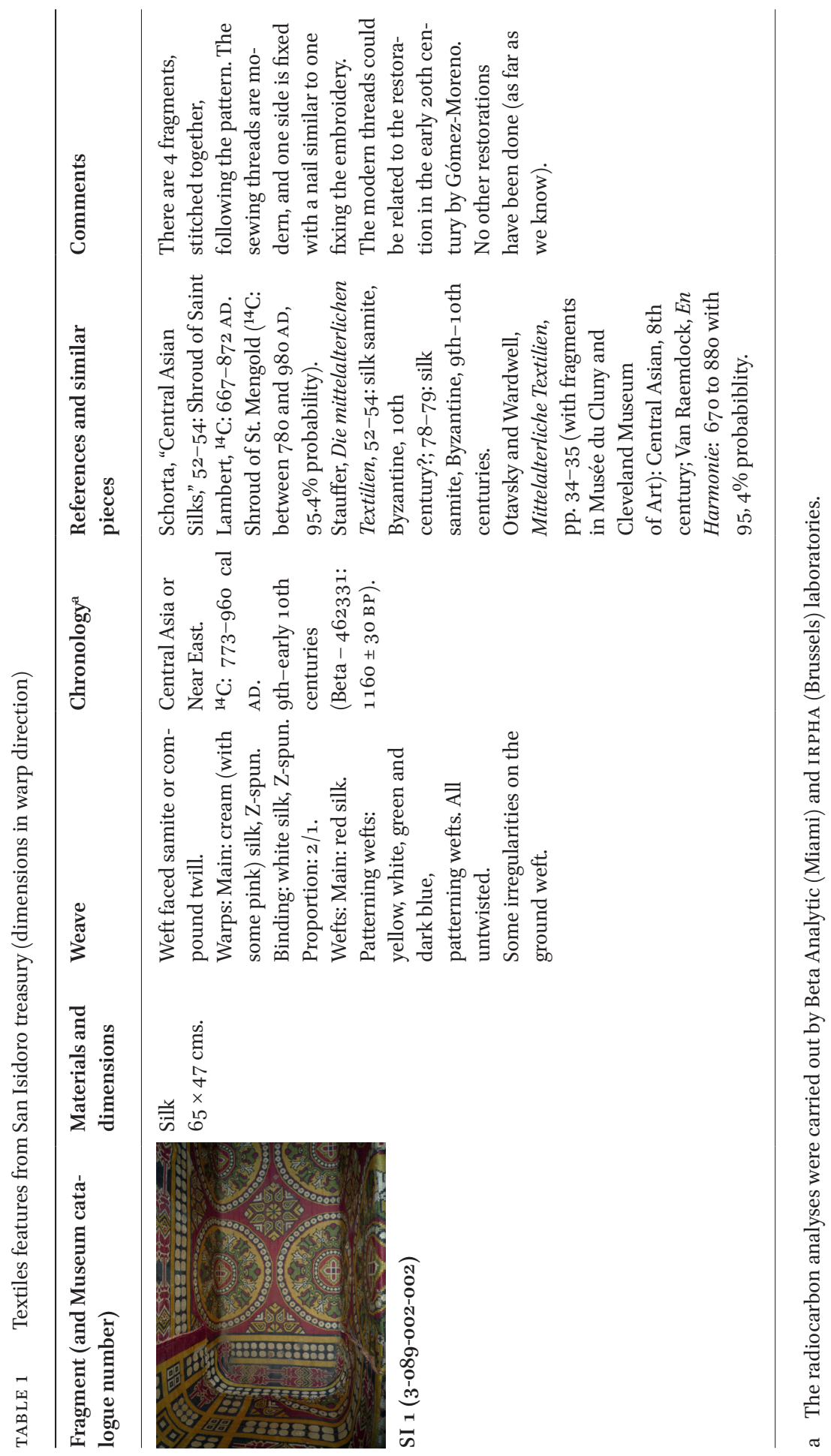




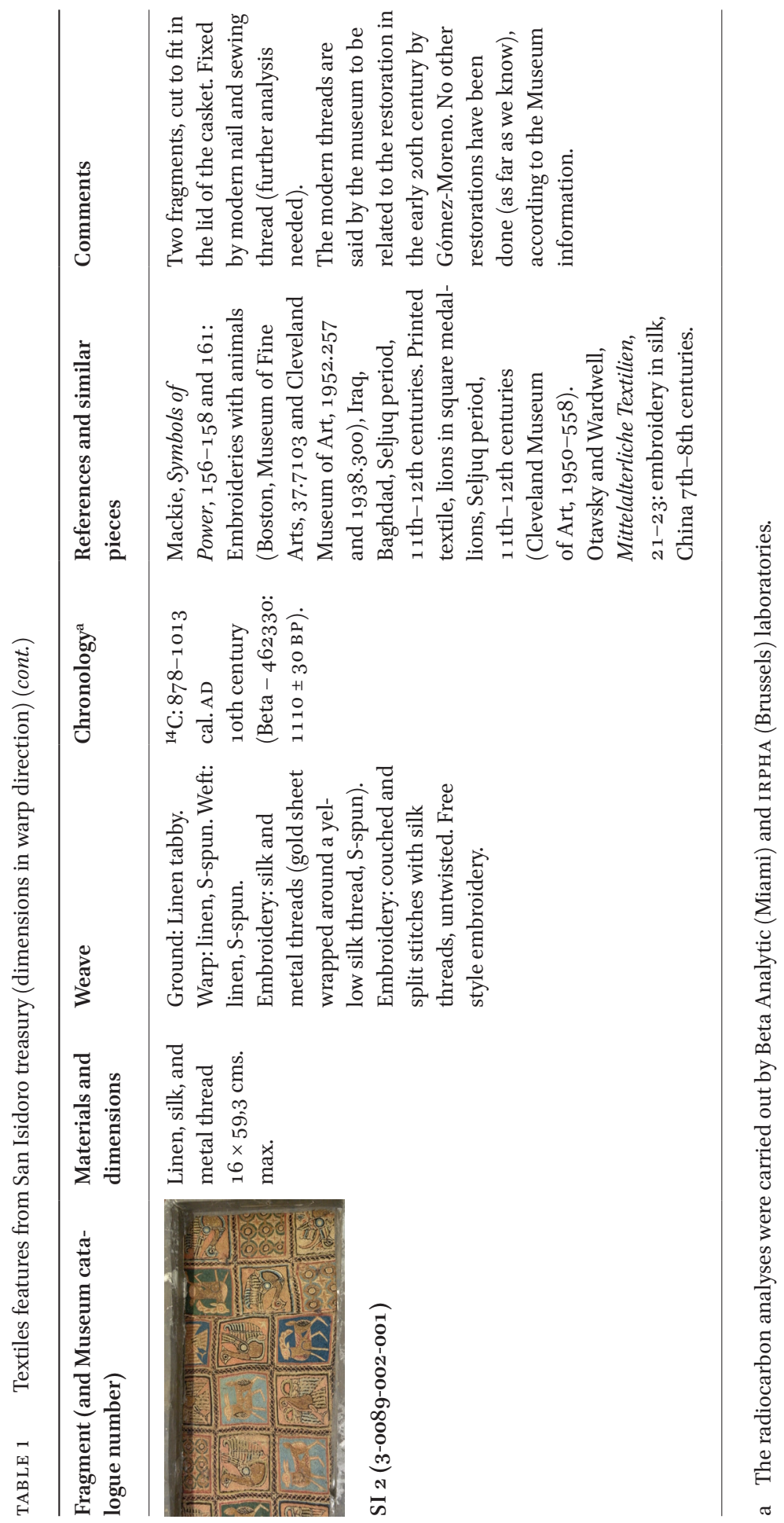




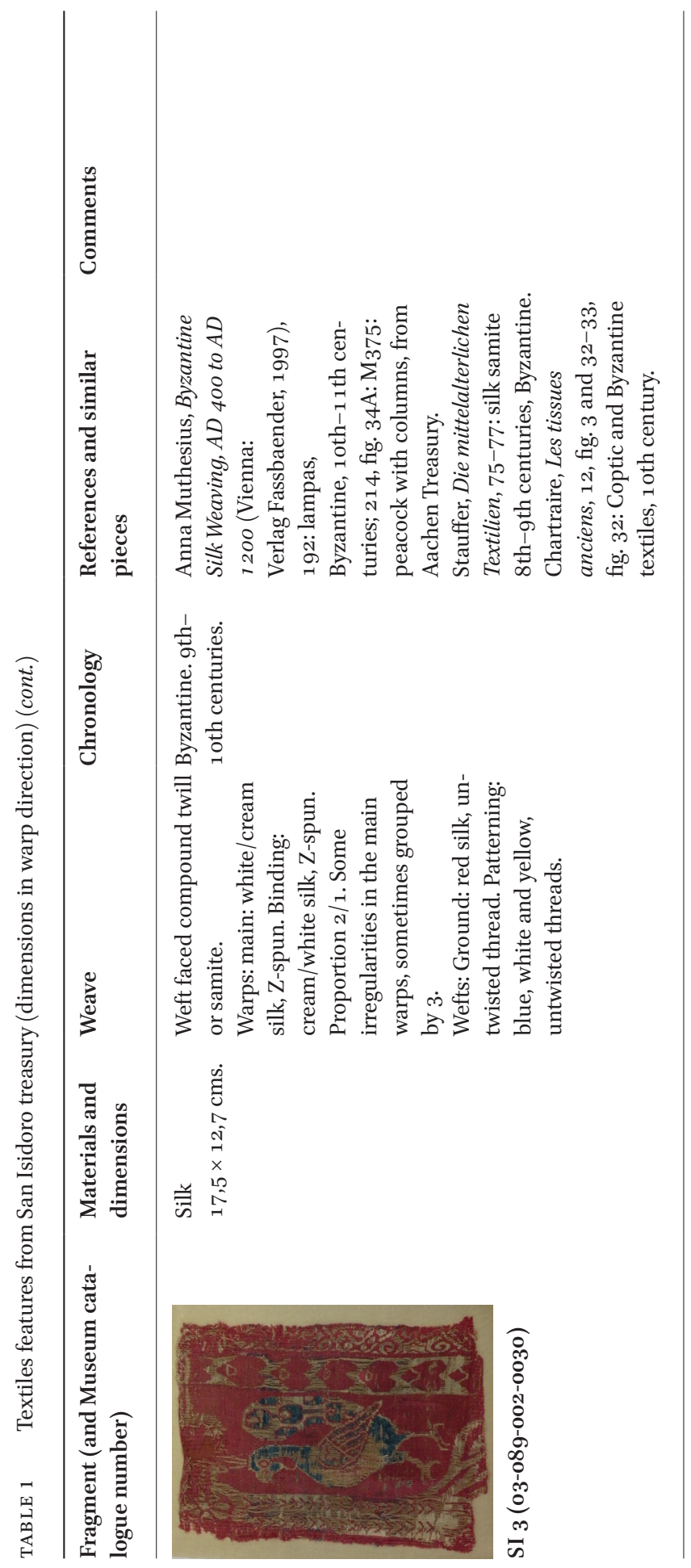




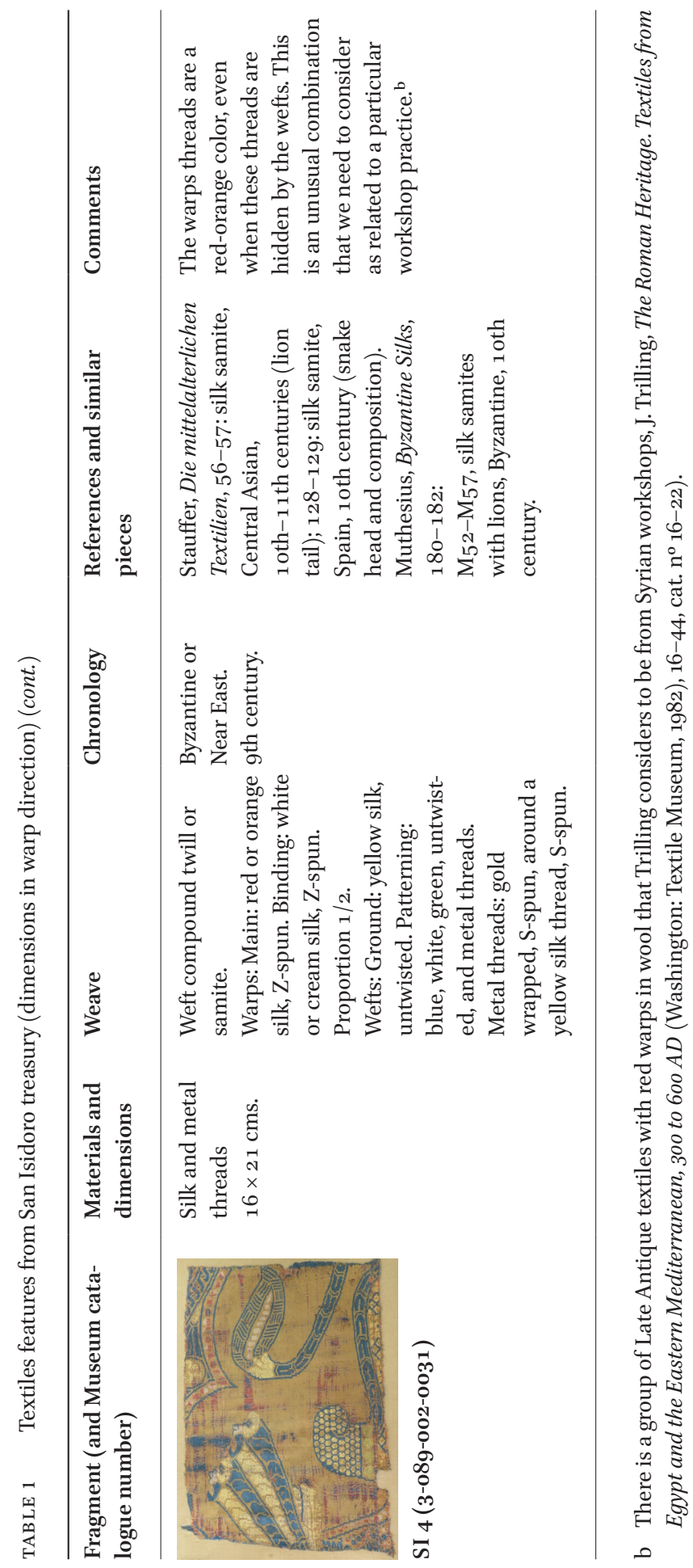




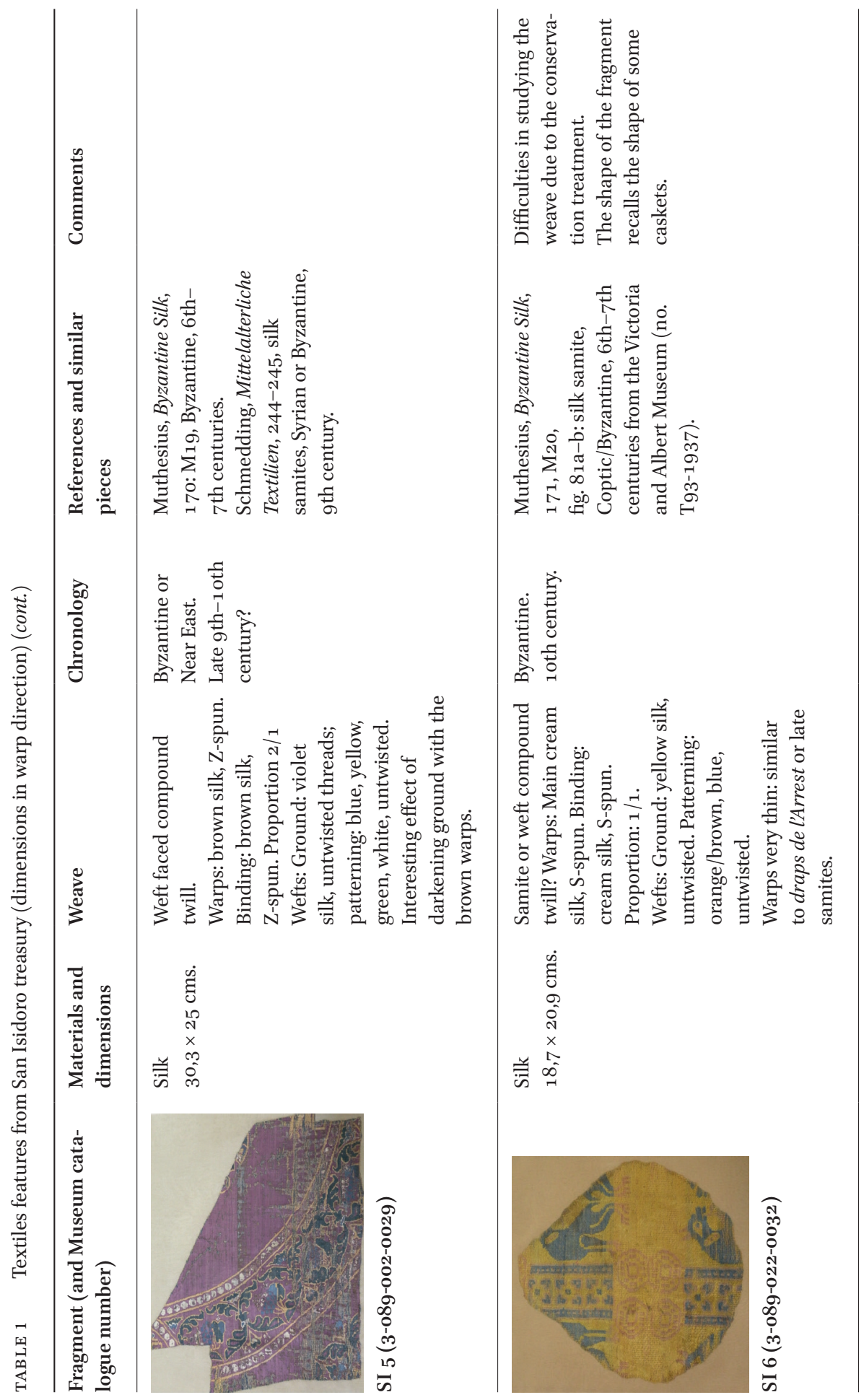




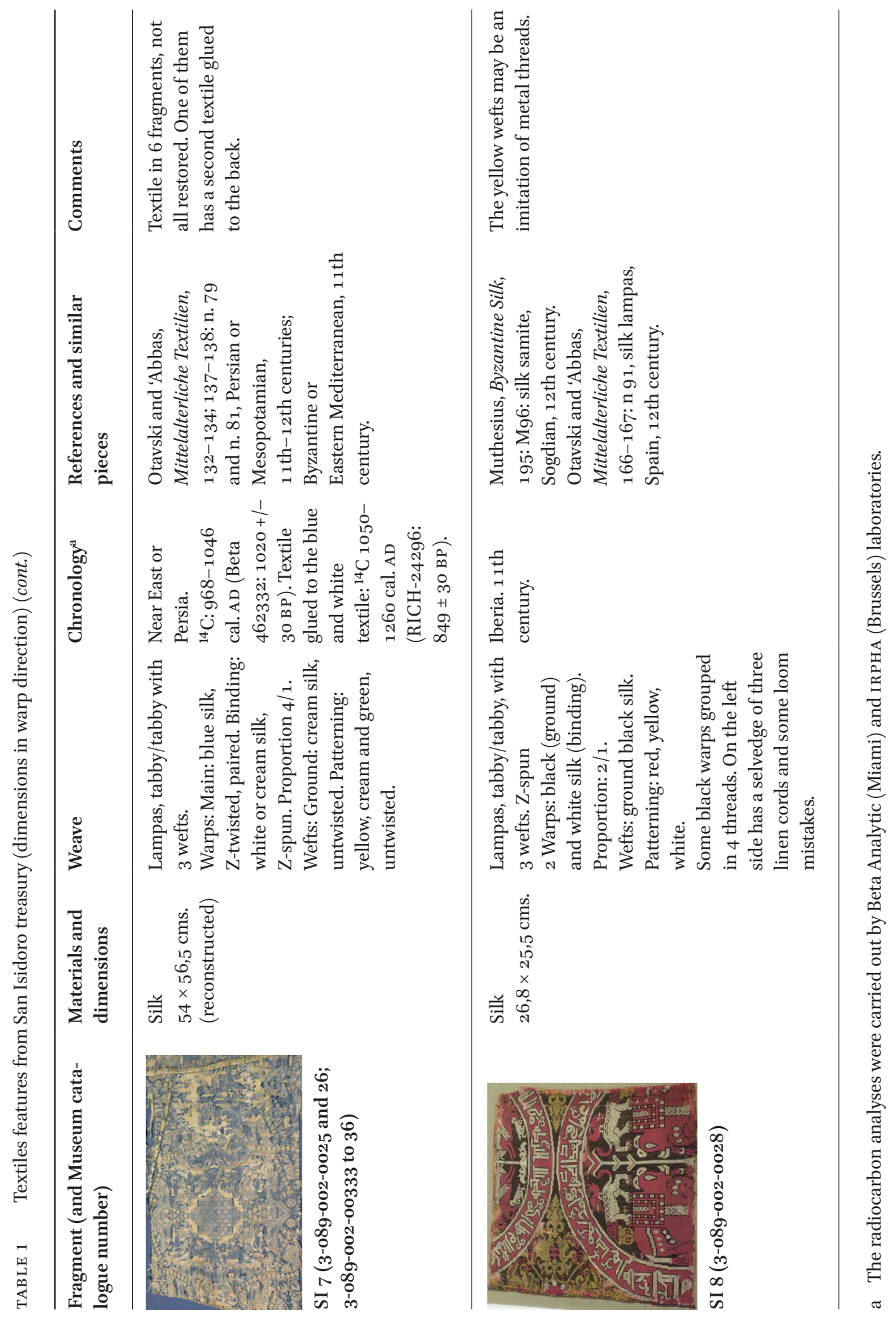




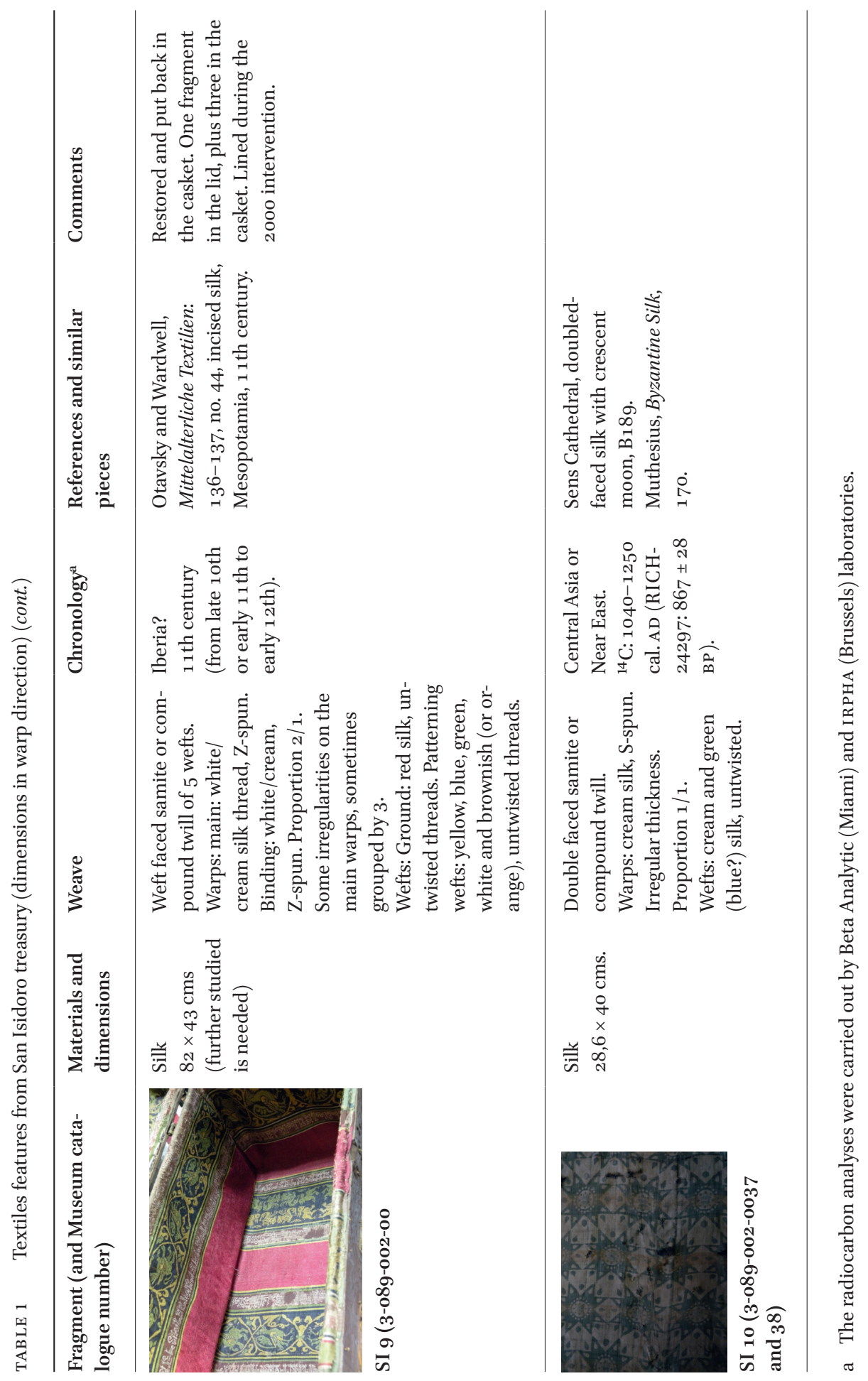




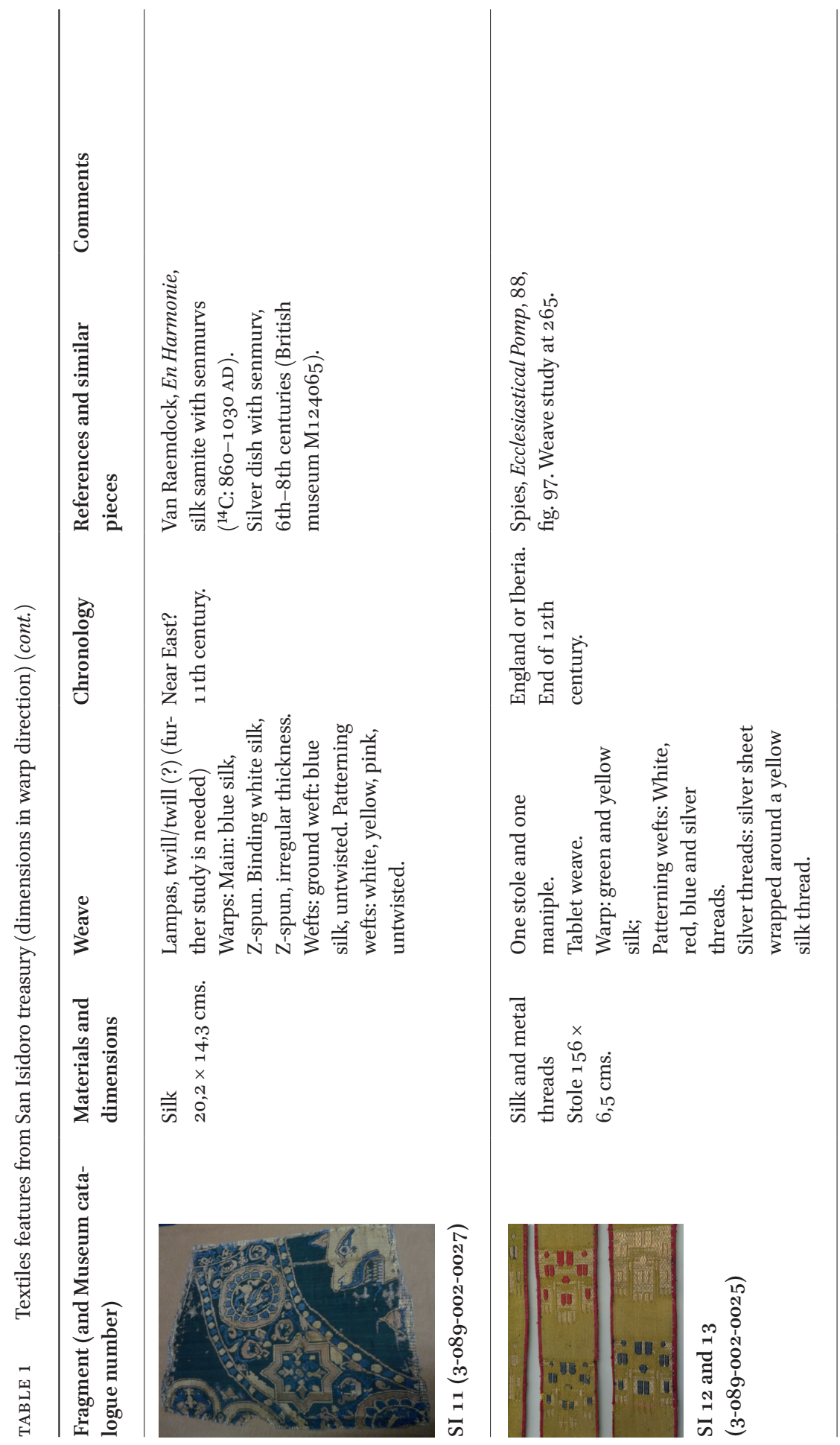




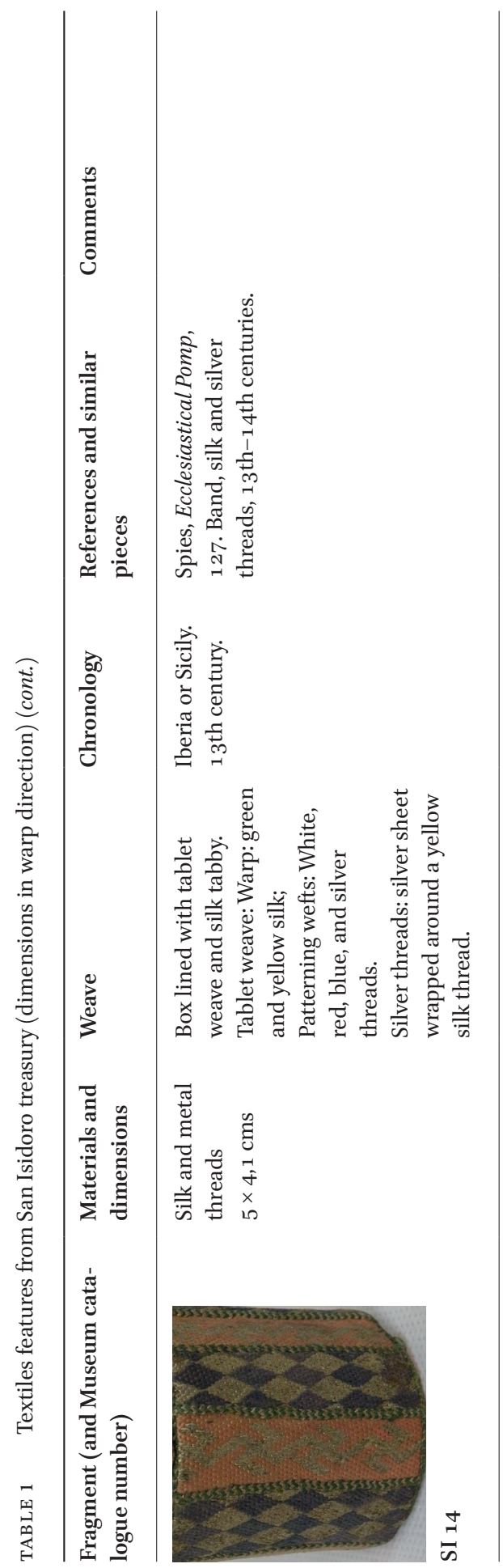

